\title{
International entrepreneurship: a critical review of the research field
}

\author{
Hugo Baier-Fuentes1, Esther Hormiga2, Paloma Miravitlles2 and Fabio Blanco Mesa3
}

1Faculty of Economic and Administrative Sciences, Universidad Católica de la Santísima Concepción, 4070129, Concepción, Chile Email: hbaier@ucsc.cl

2Department of Business, Faculty of Economics and Business, University of Barcelona, Av. Diagonal 690, 08034, Barcelona, Spain Email: ehormiga@ub.edu Email: paloma.miravitlles@ub.edu

3Escuela de Administración de Empresas, Facultad de Ciencias Económicas y Administrativas, Universidad Pedagógica y Tecnológica de Colombia, Avenida Central del Norte 39-115, 150001, Tunja, Colombia Email: fabio.blanco01@uptc.edu.co

\begin{abstract}
This study provides a comprehensive review of the International Entrepreneurship (IE) literature and analyses its evolution in relation to the criticisms made by previous reviews. For this purpose, 272 articles published in 20 journals indexed in the Journal Citation Report for the 19892015 period were analysed in depth. The results reveal that researchers have increasingly worked to address these criticisms. Nevertheless, these efforts have not been sufficient since theoretical difficulties that prevent a better understanding of the IE field continue. Therefore, this study conducts a critical discussion of these difficulties: the disparity between IE definitions, the terminological disparity between rapidly internationalising firms, and the inclusion of studies that compare entrepreneurship at the national level between countries. Finally, to improve understanding and enable further progress in IE research, recommendations and a roadmap for future research are proposed.
\end{abstract}

Keywords: international entrepreneurship; international new ventures; born global; comparative entrepreneurship; literature review. 


\section{Introduction}

This paper focuses on an interesting body of literature that arises from the intersection of two important areas of knowledge, international business (IB) and entrepreneurship, which is known as "International Entrepreneurship" (IE) (McDougall and Oviatt, 2000). One of the first appearances in the literature of the term International Entrepreneurship occurred in 1988, when John F. Morrow published his article entitled "International Entrepreneurship: a new growth opportunity". One year later, McDougall published an article comparing the new firms that chose to focus on the domestic market with those that chose to be international from the beginning. In this article, a definition of IE is proposed on which the subsequent research is based. The term IE is defined as follows: "The development of international new ventures or start-ups that, from their inception, engage in international business, thus viewing their operating domain as international from the initial stages of the firm's operation" (McDougall, 1989, p.388). However, several authors consider the starting point of the IE field the publication of an article by Oviatt and McDougall (1994), "Toward a theory of international new ventures". According to Autio (2005), this work generated a "creative tension" in the IB field because it challenged existing theories of internationalisation. Thus, for example, the Uppsala internationalisation model (Johanson and Vahlne 1977, 1990) described IE as a slow and sequential process. This description was questioned by Oviatt and McDougall (1994), who demonstrated early international activity by ventures. They pointed out that these activities were a direct result of the entrepreneur's role and the opportunities offered by advances in communications technology and transportation. This new approach, as Autio (2005) notes, created a completely new direction for IB research, forming what is now known as IE. Since its origin, this field has been characterised by the rapid growth of empirical studies focused mainly on the early internationalisation of firms with a particular focus on the phenomenon of International New Ventures (INVs), also known as Born Global Firms. According to Keupp and Gassmann (2009), the first definitions of IE marked this trend in field research. Likewise, the field has been characterised by the emergence of several theoretical studies that have continually developed "new" definitions that research IE far from the context of its phenomenological nature, the early internationalisation of firms. Zahra (1993) was one of the first researchers to expand IE beyond the early internationalisation of firms. He considered internationalisation itself an entrepreneurial activity and therefore encouraged future studies to consider IE from the previous perspective of internationalisation, not only in the new ventures but also in large and established companies. Subsequently, several theoretical studies following Zahra (1993) have taken into account these recommendations and have incorporated important changes in both the domain and the field definition (McDougall et al., 2014; McDougall and Oviatt, 1997; Oviatt and McDougall, 1994, 2005a; Wright and Ricks, 1994; Zahra et al., 2014; Zahra and George, 2002). In fact, one of the most recent literature reviews in this field, developed by Jones et al. (2011), confirmed the changes in the IE domain and found that the field involves three main streams: (1) studies on entrepreneurial internationalisation, (2) comparisons of domestic entrepreneurial activities between countries or cultures, and (3) comparisons of entrepreneurial internationalisation among countries or cultures. The last definition of this 
field was made by Zahra et al. (2014), who, together with his collaborators, call for further broadening the boundaries of IE, intersecting the literature of this field with that of social entrepreneurship (McDougall et al., 2014). This definition is similar to other highly cited definitions, such as that of Oviatt and McDougall (2005a), and presents great coherence with current social phenomena. Hence, IE is defined today as follows: ...The recognition, formation, evaluation, and exploitation of opportunities across national borders to create new businesses, models, and solutions for value creation, including financial, social, and environmental... (Zahra et al., 2014, p.138). These changes in the scope of IE have generated important criticism and debate. Coviello and Jones (2004) performed a literature review in which they found that IE has experienced an imbalance in its theoretical integration since studies tend to favour either the side of IB or entrepreneurship. Likewise, Keupp and Gassmann (2009) suggest that the lack of rigour in the IE definition has caused problems with fragmentation and theoretical integration and that the IE field has been progressing in an uncertain line of development. Subsequently, Jones et al. (2011) discussed the comments of Keupp and Gassmann (2009) and developed a conceptual repository in an attempt to demonstrate that despite the apparent weaknesses and fragmentation, the IE field has the potential to continue to develop quality investigations and establish itself as an independent field of research.

Despite the different definitions, on-going debates and criticisms, the IE field has been growing in scientific productivity. Consequently, it is important to analyse the directions of the new literature to understand how the field has developed. Hence, the main aim of this research is to examine the direction of the recent literature in IE. In this review, we consider the criticisms and discussion in recent years presented by authors such as Coviello and Jones (2004) and Keupp and Gassmann (2009). We conduct a review of 272 articles published in international journals that are indexed in the Web of Science (WoS) during the period between 1989 and 2015. We give special attention to research published in the last five years. The findings provide an updated and clear picture of progress in the IE literature in recent years and a critical viewpoint. Some proposals that seek to unify certain paradigms of IE are also included. In addition, this work reduces the barriers to a better understanding of the IE field. Finally, it offers an analysis of the latest frameworks and theoretical perspectives that are expected to constitute future IE research. The rest of the paper is organised as follows. In the following section, the methodology employed to obtain scientific papers and develop the literature review is presented. The next section describes the research findings. This section is followed by a discussion and, finally, the main conclusions from the study. The most important areas for future research are also identified.

\section{Methodology}

The literature review is divided into five distinct stages drawing on the established methods (Both et al., 2014).1 Thus, we have limited the analysis to academic articles published in journals with the highest impact factor (IF) according to internationally renowned databases. This criterion is common in previous literature reviews (Brush et al., 2008; Dean et al., 2007; Keupp and Gassmann, 2009). Therefore, for article identification and retrieval, we 
have used the WoS database since it is considered one of the main academic databases for the assessment of scientific output worldwide. WoS covers more than 15,000 journals and $50,000,000$ articles. Although there are other alternative databases, it is expected that the material included in WoS has the highest quality standards (Merigó et al., 2015). The search was conducted through keywords in accordance with the concepts included in the IE field. Furthermore, we used the search engine of the Core Collection of the WoS. The chosen keywords were "International* Entrepreneur*", "Entrepreneur* International*", "International* Entrepreneur* Behavi*", "International* Entrepreneur* Opportunit*", "Rapid* International* Firm*", "Earl* International* Firm*", "International New* Ventur*", "Born Global* Firm*", "Export* Entrepreneur*", "International* Corporat* Entrepreneur*" and "International* Intrapreneur*". To ensure complete coverage of IE literature in the different academic fields, we made a pre-selection of articles published in the top five journals according to the highest impact factor using the Journal Citation Report for 2014 within the four main areas of Management and Business. Doctoral theses, interviews, editorial notes, chapters of books, books reviews, and conference proceedings and symposium presentations were excluded. The selected areas and journals were (1) International Business field (Journal of International Business Studies, Journal of International Marketing, Journal of World Business, International Marketing Review, International Business Review); (2) Entrepreneurship field (Journal of Business Venturing, Entrepreneurship Theory and Practice, Strategic Entrepreneurship Journal, International Small Business Journal, Small Business Economics); (3) Management field (Academy of Management Review, Academy of Management Journal, Journal of Management, International Journal of Management Reviews, Strategic Management Journal) and (4) Technological and Innovation Management field (Research Policy, Technovation, Journal of Engineering and Technology Management, Technological Forecasting and Social Change, Journal of Product and Innovation Management). 
Table 1 Journals selected for study

\begin{tabular}{clccc}
\hline No. & Name of journal & I.F. & No. Art. & $\%$ of total \\
\hline 1 & Academy of Management Review & 7.475 & 1 & $0.37 \%$ \\
2 & Academy of Management Journal & 6.448 & 5 & $1.85 \%$ \\
3 & Journal of Management & 6.071 & 4 & $1.48 \%$ \\
4 & International Journal of Management Reviews & 3.857 & 2 & $0.74 \%$ \\
5 & Journal of Business Venturing & 3.678 & 18 & $6.64 \%$ \\
6 & Journal of International Business Studies & 3.563 & 36 & $13.28 \%$ \\
7 & Strategic Management Journal & 3.341 & 2 & $0.74 \%$ \\
8 & Entrepreneurship Theory and Practice & 3.144 & 21 & $7.75 \%$ \\
9 & Research Policy & 3.117 & 1 & $0.37 \%$ \\
10 & Journal of International Marketing & 3.100 & 16 & $5.90 \%$ \\
11 & Technovation & 2.526 & 2 & $0.74 \%$ \\
12 & Journal of World Business & 2.388 & 35 & $12.92 \%$ \\
13 & Journal of Engineering and Technology Management & 2.060 & 1 & $0.37 \%$ \\
14 & Technological Forecasting and Social Change & 2.058 & 1 & $0.37 \%$ \\
15 & Strategic Entrepreneurship Journal & 2.000 & 8 & $2.95 \%$ \\
16 & International Marketing Review & 1.865 & 30 & $11.07 \%$ \\
17 & International Small Business Journal & 1.800 & 12 & $4.43 \%$ \\
18 & Small Business Economics & 1.795 & 15 & $5.54 \%$ \\
19 & International Business Review & 1.713 & 62 & $22.88 \%$ \\
20 & Journal of Product and Innovation Management & 1.696 & 0 & $0.00 \%$ \\
\hline & & Total & 272 & $100.00 \%$ \\
\hline & & & & \\
\hline
\end{tabular}

Source: Retrieved from WoS 2015

Based on the criteria previously stated, we obtained a sample of 344 articles. Subsequently, these articles were read and reviewed to obtain the final sample. To obtain the final sample, the following exclusion criteria were considered. First, included articles should be published between 1989 and 2015. Second, the included articles should be focused specifically on the entrepreneurial internationalisation of any actor (organisations, groups, or individuals) as defined by Oviatt and McDougall (2005a) and Zahra et al. (2014). Third, the articles included in the sample should indicate explicitly, either through keywords, abstract or content, that they are contributing to the IE field. According to the mentioned criteria, 72 articles were excluded because they mentioned anecdotal information, considered similar topics without relation to entrepreneurial internationalisation or did not present a relevant contribution to the IE field. Thus, a total of 272 articles were selected (due to space limitations, the full list can be obtained from the leading author upon request). The size of this sample allows us to conduct a review of the literature deemed representative of recent trends in IE. However, given the nature of a "cutting-edge research area", the final selection of articles is inevitably not free of omissions. This literature review needs to be understood as a general survey of the state-of-the-art IE research, comprising articles that have had the greatest impact in this research field. 


\section{Results}

\subsection{Evolution of published articles in the field of IE}

In 1988, John F. Morrow published an article in the New Management journal entitled "International Entrepreneurship: a new growth opportunity", in which the concept of IE is introduced. Since then, the number of articles published on IE has risen at an almost exponential rate. Figure 1 shows the quantitative evolution of this field of research between 1989 and 2015. Based on a percentage analysis of IE articles published per year, the general tendency of the publications is increasing, but there have been some variations in the trend in the last few years (see Figure 1).

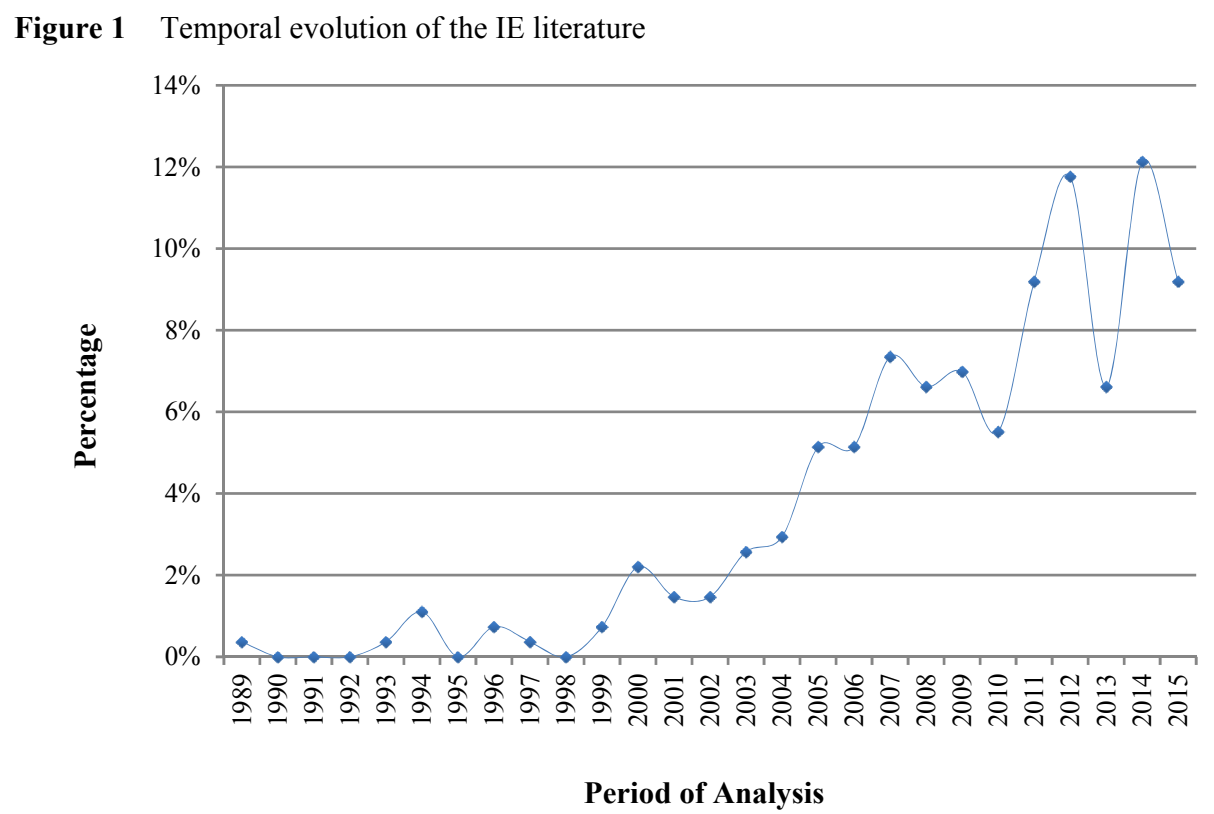

Source: Retrieved from WoS 2015

If the evolution of published articles according to the orientation of journals is analysed, a number of interesting results emerge. Table 2 shows that $66 \%$ of the articles analysed were published in journals oriented towards the IB field, concentrated mainly in four journals: International Business Review (62), Journal of International Business Studies (36), Journal of World Business (35) and International Marketing Review (30). The remaining articles were published in journals oriented towards the entrepreneurship field $(27.3 \%)$, the management field (4.8\%), and other journals of technological and innovation management $(1.8 \%)$. 
Table 2 Evolution in IE papers by journal type

\begin{tabular}{|c|c|c|c|c|}
\hline Journal types & $\leq 2004$ & $2005-2009$ & $2010-2015$ & Total \\
\hline International Business & 18 & 66 & 95 & 179 \\
\hline International Business Review & 5 & 17 & 40 & 62 \\
\hline Journal of International Business Studies & 5 & 19 & 12 & 36 \\
\hline Journal of World Business & 0 & 16 & 19 & 35 \\
\hline International Marketing Review & 2 & 12 & 16 & 30 \\
\hline Journal of International Marketing & 6 & 2 & 8 & 16 \\
\hline Entrepreneurship & 14 & 15 & 45 & 74 \\
\hline Entrepreneurship Theory and Practice & 1 & 5 & 15 & 21 \\
\hline Journal of Business Venturing & 8 & 0 & 10 & 18 \\
\hline Small Business Economics & 5 & 3 & 7 & 15 \\
\hline International Small Business Journal & 0 & 2 & 10 & 12 \\
\hline Strategic Entrepreneurship Journal & 0 & 5 & 3 & 8 \\
\hline Management & 6 & 4 & 3 & 14 \\
\hline Academy of Management Journal & 4 & 0 & 1 & 5 \\
\hline Academy of Management Review & 0 & 1 & 0 & 1 \\
\hline International Journal of Management Review & 0 & 0 & 2 & 2 \\
\hline Journal of Management & 1 & 3 & 0 & 4 \\
\hline Strategic Management Journal & 1 & 0 & 1 & 2 \\
\hline Technological and Innovation Management & 1 & $\mathbf{0}$ & 4 & 5 \\
\hline $\begin{array}{l}\text { Journal of Engineering and Technology } \\
\text { Management }\end{array}$ & 0 & 0 & 1 & 1 \\
\hline Research Policy & 0 & 0 & 1 & 1 \\
\hline Technological Forecasting and Social Change & 1 & 0 & 0 & 1 \\
\hline Technovation & 0 & 0 & 2 & 2 \\
\hline Journal of Product and Innovation Management & 0 & 0 & 0 & 0 \\
\hline Total & 39 & 85 & 147 & 272 \\
\hline
\end{tabular}

These results contradict the findings of the other literature reviews reported, such as Keupp and Gassmann (2009), who found that $65 \%$ of the literature had been published in entrepreneurship journals, $24.6 \%$ in international business journals and $9.82 \%$ in management journals. These differences could be explained by the interest in recent years in considering the IE field a pattern of internationalisation instead of a phenomenon of entrepreneurial behaviour (Heidenreich et al., 2015; Jorgensen, 2014; Kalinic and Forza, 2012; Olejnik and Swoboda, 2012; Sui et al., 2012; Zahra and Mudambi, 2007). In fact, according to the results, the number of articles published until 2004 in journals of entrepreneurship and IB was similar. However, in the last decade, the IB journals published $40 \%$ more articles in the IE field compared to entrepreneurship journals. These differences can also be attributed to the different periods of analysis and the disparity of criteria used in the selection of journals and articles. 


\subsection{Analysis of the theoretical frameworks used}

As mentioned above, the IE literature is considered a specific and interdisciplinary field of research that has focused primarily on the rapid internationalisation of new firms. Classical theories of international business, including the sequential model of internationalisation and the network theory, do not adequately explain the phenomenon when they are addressed independently, so a more holistic view of the firm is required. Likewise, the theoretical approaches to the study of entrepreneurship, including the economic, psychological, sociocultural/institutional and managerial approaches (Veciana, 2007), seek to explain why new ventures emerge and do not consider the process of business internationalisation. Consequently, a great deal of the IE literature continues to build on conceptual schemes and models that integrate different topics, conceptual and theoretical frameworks stemming from different research areas (Jones and Coviello, 2005; Rialp et al., 2005). Taking into account this interdisciplinary nature of research in IE, we have analysed the articles on the basis of the theoretical perspectives that they employed (see Table 3).

Table 3 Number of references grouped by theoretical frameworks

\begin{tabular}{lcc}
\hline Theoretical frameworks & No. of times used & Percent \\
\hline Non-Specific/Multiples ${ }^{\mathrm{a}}$ & 103 & $37.9 \%$ \\
Resource-Based View & 44 & $16.2 \%$ \\
Internationalisation Theory & 17 & $6.3 \%$ \\
Neointitutional Theory & 16 & $5.9 \%$ \\
Strategic Orientation & 16 & $5.5 \%$ \\
Organisational Learning & 13 & $4.8 \%$ \\
Alliance or Interfirm Network Theory & 13 & $4.8 \%$ \\
Social Network Theory & 10 & $3.7 \%$ \\
Opportunities-Based View & 10 & $3.7 \%$ \\
Strategic Entrepreneurship & 7 & $2.9 \%$ \\
Dynamic Capabilities & 5 & $1.8 \%$ \\
Economic Geography & 4 & $1.5 \%$ \\
Experiential Learning & 3 & $1.1 \%$ \\
Industrial Economics & 3 & $1.1 \%$ \\
Social Cognition & 2 & $0.7 \%$ \\
Effectuation Theory & 2 & $0.7 \%$ \\
Transaction Cost Theory & 1 & $0.4 \%$ \\
Agency Theory & 1 & $0.4 \%$ \\
Economic Theory of Entrepreneurship & 1 & $0.4 \%$ \\
Attention-based View (Ocasio) & 1 & $0.4 \%$ \\
\hline Source: Own & $5 \%$
\end{tabular}

Source: Own elaboration based on Keupp and Gassmann (2009) classification

Note: $\quad{ }^{a}$ This count also comprises articles where a theoretical framework is not to be readily expected (e.g., literature reviews, editorial articles). 
Table 3 shows that several theoretical frameworks have been used in the IE field. Some previous reviews, such as Keupp and Gassmann (2009), have criticised an alleged imbalance between the entrepreneurship and international business fields. They noted that studies tend to use frameworks derived from the theories of IB at the expense of entrepreneurship theories. The results show that this trend is beginning to be reversed and that the IE field is starting to gradually adopt new theoretical frameworks derived from entrepreneurship, which may be broad in scope and involve all streams of IE. However, this "theoretical imbalance" has not been corrected; therefore, it remains necessary to further develop the entrepreneurship components in this field (this point is discussed in greater detail in the next section). Likewise, the results show that studies continue to be developed using diverse theoretical frameworks, in agreement with the results of Keupp and Gassmann (2009). Nevertheless, although these authors consider this result contrary to the progress of IE literature, it is evident that these articles give value to the field since they show that it is possible to combine different theories and take advantage of different lenses to examine research questions of a dynamic phenomenon, such as entrepreneurial internationalisation.

\subsection{Analysis of the methodologies used}

As far as research methodologies are concerned, $76.5 \%$ of the methodologies are of an empirical nature (208 studies), and $23.5 \%$ are of a markedly theoretical nature (64 studies). Based on the above, the findings also highlight that a significant growth of empirical studies has occurred in the last decade. In fact, $87 \%$ of studies of this type were published in the period 2006-2015. This reflects a greater acceptance of certain theoretical bases and concepts within the research field. The analysis of empirical studies indicates that $64 \%$ of these studies (133 studies) used some quantitative methodology, compared with 69 studies that used a case study methodology (33\%) and 6 studies with mixed methodologies (3\%). Furthermore, $66 \%$ of the quantitative studies are concentrated in five journals, of which four correspond to IB journals. These include International Business Review (26), Journal of International Business Studies (21), Journal of World Business (17), International Marketing Review (12) and Small Business Economics (12). The journals that include most of the case studies (81\%) include International Business Review (27), Journal of World Business (11) and International Marketing Review (13).

Previous literature reviews criticised IE empirical research as characterised by the development of static studies that failed to capture the complex processes of entrepreneurial internationalisation (Coviello and Jones, 2004; Keupp and Gassmann, 2009). It is assumed that longitudinal research would improve the understanding of entrepreneurial internationalisation. The results show that after the article written by Coviello and Jones (2004), longitudinal studies showed modest growth (see Table 4). It is noteworthy that of the 29 longitudinal studies found, $60 \%$ were published in the last five years. Nevertheless, most of these articles were positivist and unable to capture relationships over time, which influences international entrepreneurial behaviour. Hence, it is evident that researchers have not helped to achieve the proposed objectives for the field. 
Table 4 Methodologies used in IE research

\begin{tabular}{|c|c|c|}
\hline \multicolumn{3}{|c|}{ References } \\
\hline $\begin{array}{l}\text { Research } \\
\text { methodologies } \\
\text { (empirical studies) }\end{array}$ & Cross-sectional studies & Longitudinal studies \\
\hline $\begin{array}{l}\text { Quantitative } \\
\text { Methodology }\end{array}$ & $\begin{array}{l}\text { McDougall (1989); McDougall and Oviatt } \\
\text { (1997); Jones (1999); Thomas and Muller } \\
\text { (2000); Burgel and Murray (2000); Zahra } \\
\text { et al. (2000); Yeoh (2000); Shrader (2001); } \\
\text { Kotha et al. (2001); Moen and Servais } \\
\text { (2002); Yli-Renko et al. (2002); Moen } \\
\text { (2002); Carpenter et al. (2003); Riddle and } \\
\text { Gillespie (2003); Kundu and Katz (2003); } \\
\text { Ibeh (2003); Knight and Cavusgil (2004); } \\
\text { Dimitratos et al. (2004); Contractor and } \\
\text { Kundu (2004); De Clercq et al. (2005); } \\
\text { Rothaermel et al. (2006); Pla-Barber and } \\
\text { Escribá-Esteve (2006); Mittelstaeds et al. } \\
\text { (2006); Kropp et al. (2006); Fan and } \\
\text { Phan (2007); Nadkarni and Pérez (2007); } \\
\text { Freeman and Cavusgil (2007); Kuivalainen } \\
\text { et al. (2007); Zucchella et al. (2007); Zhou } \\
\text { (2007); Gleason and Wiggenhorn (2007); } \\
\text { Presutti et al. (2007); Mudambi and Zahra } \\
\text { (2007); Yiu et al. (2007); Zhou et al. } \\
\text { (2007); Acedo and Jones (2007); Fernhaber } \\
\text { et al. (2008); Jantunen et al. (2008); } \\
\text { Hessels et al. (2008); Cheng and Yu } \\
\text { (2008); Tuppura et al. (2008); López et al. } \\
\text { (2009); Reuber and Fischer (2009); } \\
\text { Schwens and Kabst (2009); Morgan- } \\
\text { Thomas and Jones (2009); Filatotchev } \\
\text { et al. (2009); Dai and Liu (2009); Zhou } \\
\text { et al. (2010); Khavul et al. (2010); Hugues } \\
\text { et al. (2010); Khavul et al. (2010); Musteen } \\
\text { et al. (2010); Bruneel et al. (2010); } \\
\text { Lu et al. (2010); Hashai, N. (2011); } \\
\text { Ellis (2011); Nadkarni et al. (2011); } \\
\text { Cuervo-Cazurra (2011); Liu et al. (2011); } \\
\text { Manolova et al. (2011); Schwens and } \\
\text { Kabst (2011); Tang (2011); Ganotakis and } \\
\text { Love (2012); Zhou et al. (2012); } \\
\text { Gabrielsson et al. (2012); Efrat and } \\
\text { Shoham (2012); Ripolles and Blesa (2012); } \\
\text { Riding et al. (2012); Sciascia et al. (2012); } \\
\text { Ripolles et al. (2012); Dimitratos et al. } \\
\text { (2012); Robson et al. (2012); Desa, G. } \\
\text { (2012); Boso et al. (2012); Sundqvist et al. } \\
\text { (2012); Olejnik and Swoboda (2012); } \\
\text { Li et al. (2012); Sinkovics et al. (2012); } \\
\text { Hagen et al. (2012); Boso et al. (2012); } \\
\text { Kiss et al. (2013); Uner et al. (2013); } \\
\text { Baum et al. (2013); Yamakawa et al. } \\
\text { (2013); Efrat and Shoham (2013); Bloemer } \\
\text { et al. (2013); Calabro et al. (2013); }\end{array}$ & $\begin{array}{l}\text { Autio et al. (2000); Westhead } \\
\text { et al. (2001); George et al. } \\
\text { (2005); Coeurderoy and } \\
\text { Murray (2008); De Clercq } \\
\text { et al. (2008); Filatotchev and } \\
\text { Piesse (2009); Fernhaber et al. } \\
\text { (2009); Arranz and De } \\
\text { Arroyabe (2009); Colantone } \\
\text { and Sleuwaegen (2010); } \\
\text { Ramos et al. (2011); Hessels } \\
\text { and van Stel (2011); Bell et al. } \\
\text { (2012); Sui et al. (2012); } \\
\text { LiPuma et al. (2012); } \\
\text { Sleuwaegen and Onkelinx } \\
\text { (2014); Neville et al. (2014); } \\
\text { Sui and Baum (2014); Mohr } \\
\text { and Batsakis (2014); Gallego } \\
\text { and Casillas (2014); Gonzalez- } \\
\text { Pernia and Pena-Legazkue } \\
\text { (2015); Murmann et al. (2015) }\end{array}$ \\
\hline
\end{tabular}


Table 4 Methodologies used in IE research (continued)

\begin{tabular}{|c|c|c|}
\hline \multicolumn{3}{|c|}{ References } \\
\hline $\begin{array}{l}\text { Research } \\
\text { methodologies } \\
\text { (empirical studies) }\end{array}$ & Cross-sectional studies & Longitudinal studies \\
\hline & $\begin{array}{l}\text { Milanov and Fernhaber (2014); Nakos } \\
\text { et al. (2014); Tolstoy, D. (2014); De Clercq } \\
\text { and Zhou (2014); Zhou and Wu (2014); } \\
\text { Chetty et al. (2014); Gnizy et al. (2014); } \\
\text { Hohenthal et al. (2014); Cannone and } \\
\text { Ughetto (2014); Helm and Gritsch (2014); } \\
\text { De Clercq et al. (2014); Brouthers, K. } \\
\text { (2015); Liet al. (2015); Musteen et al. } \\
\text { (2015); Cumming et al. (2015); Williams } \\
\text { and Gregoire (2015); Khalid and Bhatti } \\
\text { (2015); Baum et al. (2015); Sui et al. } \\
\text { (2012); Wang and Liu (2015); Casillas } \\
\text { et al. (2015); Fernández-Mesa and Alegre } \\
\text { (2015); Wu and Voss (2015); Johanson } \\
\text { and Martin (2015); Gerschewski and } \\
\text { Xiao (2015) }\end{array}$ & \\
\hline $\begin{array}{l}\text { Qualitative } \\
\text { Methodology }\end{array}$ & $\begin{array}{l}\text { McAuley, A. (1999); Sharma and } \\
\text { Blomstermo (2003); Crick et al. (2003); } \\
\text { Andersson (2004); Crick and Spence } \\
\text { (2005); Harris and Wheeler (2005); } \\
\text { Coviello, N. (2006); Spence and Crick } \\
\text { (2006); Sullivan and Weerawardena } \\
\text { (2006); Prashantham and McNaughton } \\
\text { (2006); Gassmann and Keupp (2007); } \\
\text { Boojihawona et al. (2007); Styles and } \\
\text { Genua (2008); Nordman and Melen } \\
\text { (2008); Di Gregorio et al. (2008); } \\
\text { Gabrielsson et al. (2008); Liu et al. } \\
\text { (2008); Perks and Hugues (2008); Evers } \\
\text { and Knight (2008); Bingham, C. (2009); } \\
\text { Chandra et al. (2009); Kocak and } \\
\text { Abimbola (2009); Crick, D. (2009); } \\
\text { Tolstoy and Agndal (2010); Dimitratos } \\
\text { et al. (2010); Huan and Pervez (2010); } \\
\text { Vasilchenko and Morrish (2011); Kontinen } \\
\text { and Ojala (2011); Middleton et al. (2011); } \\
\text { Gabrielsson and Gabrielsson (2011); } \\
\text { O'Gorman and Evers (2011); Lindstrand } \\
\text { et al. (2011); Riddle and Brinkerhoff } \\
\text { (2011); Bingham and Davis (2012); Evers } \\
\text { et al. (2012); Chandra et al. (2012); } \\
\text { Bangara et al. (2012); Fletcher and Harris } \\
\text { (2012); Kalinic and Forza (2012); da } \\
\text { Rocha et al. (2012); Kontinen and Ojala } \\
\text { (2012); Hewerdine and Welch (2013); } \\
\text { Sigfusson and Chetty (2013); Hallback and } \\
\text { Gabrielsson (2013); Sigfusson and Harris } \\
\text { (2013); Taylor and Jack (2013); Freeman } \\
\text { et al. (2013); Vissak and Francioni (2013); }\end{array}$ & $\begin{array}{l}\text { Kuemmerle (2002); Chetty } \\
\text { and Campbell-Hunt (2004); } \\
\text { McGaughey, S. (2007); Zhang } \\
\text { and Dodgson (2007); Nasra } \\
\text { and Dacin (2010); Voudouris } \\
\text { et al. (2011); Autio et al. } \\
\text { (2011); Eriksson et al. (2014) }\end{array}$ \\
\hline
\end{tabular}


Table 4 Methodologies used in IE research (continued)

\begin{tabular}{|c|c|c|}
\hline \multicolumn{3}{|c|}{ References } \\
\hline $\begin{array}{l}\text { Research } \\
\text { methodologies } \\
\text { (empirical studies) }\end{array}$ & Cross-sectional studies & Longitudinal studies \\
\hline & $\begin{array}{l}\text { Shin and Lee (2013); Amoako and Lyon } \\
\text { (2014); Hewerdine et al. (2014); Jorgensen } \\
\text { (2014); Dimitratos et al. (2014); Glavas } \\
\text { and Mathews (2014); Loane et al. (2014); } \\
\text { Kalinic et al. (2014); Pruthi et al. (2014); } \\
\text { Tan and Mathews (2015); Heidenreich } \\
\text { et al. (2015); Vissak and Masso (2015); } \\
\text { Oparaocha (2015) }\end{array}$ & \\
\hline $\begin{array}{l}\text { Mixed } \\
\text { Methodology }\end{array}$ & $\begin{array}{l}\text { Knight et al. (2004); Luthans and Ibrayeva } \\
\text { (2006); Loane and Bell (2006); Loane et al. } \\
\text { (2007); Di Gregorio et al (2009); } \\
\text { Gerschewski et al. (2015) }\end{array}$ & \\
\hline
\end{tabular}

Note: The full list of articles can be obtained from the leading author upon request.

\subsection{Analysis of the unit of study}

A relevant factor in empirical studies is the unit selected for analysis, which is closely linked to the choice of theoretical approach and the research methodology. According to Oviatt and McDougall (2005a), researchers can study IE by focusing on three units of analysis: organisation, teams, and individuals. In the IE literature, these actors are considered international entrepreneurs since they are the ones who discover, promote, assess and take advantage of international opportunities (McDougall et al., 2014). The results of this review show that the empirical literature focuses unequally on these three units of analysis (see Table 5). Of the 208 empirical articles analysed, $84 \%$ focus on the firm or organisation as their integral unit of analysis, $14 \%$ focus on the individual entrepreneur as their central object of study, and the remaining $2 \%$ analyse entrepreneurial teams. These statistics are surprising because (since the emergence of IE literature) researchers have made special reference to the important role that entrepreneurs play as the main contributors responsible for the entrepreneurial internationalisation process. These findings reveal a great deficit of research on the true role of entrepreneurs in the entrepreneurial internationalisation of firms.

Table 5 Unit of analysis of empirical studies

\begin{tabular}{lcc}
\hline Object region research & No. of articles & $\%$ \\
\hline Organisation & 174 & $83.7 \%$ \\
Individuals & 29 & $13.9 \%$ \\
Entrepreneurial Teams & 5 & $2.4 \%$ \\
\hline Total & 208 & $100 \%$ \\
\hline
\end{tabular}




\subsection{Analysis of country of origin of studies}

An examination of the countries of origin (constituting the units of analysis) reveals that most studies are conducted in Europe (45\%), followed by North America (16\%) and Asia $(16 \%)$ (see Table 6). The results are consistent with those obtained by other authors (Kiss et al., 2012; Rialp et al., 2005; Yamakawa et al., 2008) and indicate that a large concentration of empirical studies is conducted in developed countries (75\%). In contrast, research conducted in emerging economies, such as those in Latin America, are a clear minority (except research performed in some countries in Asia, such as China).

Table 6 Origin of the firms examined in the empirical studies

\begin{tabular}{lcc}
\hline Object region research & No. of Articles & $\%$ \\
\hline Europe & 93 & $44.7 \%$ \\
North America & 33 & $15.9 \%$ \\
Asia & 33 & $15.9 \%$ \\
Oceania & 15 & $7.2 \%$ \\
Africa & 6 & $2.9 \%$ \\
Middle East & 4 & $1.9 \%$ \\
Latin America & 3 & $1.4 \%$ \\
Intercontinental & 21 & $10.1 \%$ \\
\hline Total & 208 & $100 \%$ \\
\hline
\end{tabular}

These marked differences between regions in relation to the scientific productivity of the IE field should be cause for concern among policy makers because the characteristics of entrepreneurs change from one culture to another (Szyliowicz and Galvin, 2010). Therefore, the importance and transferability of research with international entrepreneurs of developed economies are not applicable in less-developed contexts (Thomas and Mueller, 2000). This is a major challenge for emerging economies, and it is also a clear research opportunity for all concerned with the IE field. In other words, this field continues to need studies from emerging economies to obtain a more comprehensive and global overview of the entrepreneurial internationalisation phenomenon. In this sense, an interesting type of study involving such economies is the international comparative studies proposed by Jones et al. (2011). These studies are considered the crux of the IE field and focus on cross-country comparisons of the phenomena associated with entrepreneurial internationalisation. However, the results only reveal 21 studies of this type. These studies simply tend to compare data across nations instead of seeking real differences in international entrepreneurial behaviour between these entrepreneurs (Jones et al., 2011). Therefore, these types of studies are also necessary in the IE field.

\section{Discussion: joining criteria in the field}

In this section, we present a discussion regarding the evolution in the definition and scope of IE and perspectives for future trends in this field. We focus on the main definitions of IE. 
Finally, we provide a view of the future fields of research.

\subsection{Conceptual development of international entrepreneurship}

As mentioned above, IE has been defined on numerous occasions. During the development of the IE field, these different definitions have incorporated new concepts that come from the interpretation of studies involving phenomena related to IE. Thus, most recent definitions have integrated many concepts to offer a better understanding of IE than the first definition proposed in 1989. The main definitions offered by the most significant and most frequently cited authors over the last three decades in the IE literature are presented in Table 7.

Table 7 The main definitions of IE

\begin{tabular}{|c|c|c|}
\hline No. & Authors/year & Definitions \\
\hline 1 & $\begin{array}{l}\text { McDougall, } \\
(1989, \text { p.388) }\end{array}$ & $\begin{array}{l}\text {...as the development of international new ventures or start-ups } \\
\text { that, from their inception, engage in international business, thus } \\
\text { viewing their operating domain as international from the initial } \\
\text { stages of the firm's operation. }\end{array}$ \\
\hline 2 & Zahra (1993) & $\begin{array}{l}\text {...the study of the nature and consequences of a firm's risk-taking } \\
\text { behaviors as it ventures into international markets. }\end{array}$ \\
\hline 3 & $\begin{array}{l}\text { Wright and Ricks, } \\
(1994, \text { p.699) }\end{array}$ & $\begin{array}{l}\text {...is a firm-level activity that crosses national borders and focuses } \\
\text { on the relationship between business and the international } \\
\text { environments in which they operate. }\end{array}$ \\
\hline 4 & $\begin{array}{l}\text { McDougall and } \\
\text { Oviatt }(1997, \text { p. } 293)\end{array}$ & $\begin{array}{l}\text {...new and innovative activities that have the goal of value creation } \\
\text { and growth in business organizations across national borders. }\end{array}$ \\
\hline 5 & $\begin{array}{l}\text { McDougall and } \\
\text { Oviatt, }(2000, \text { p. } 903)\end{array}$ & $\begin{array}{l}\text {...A combination of innovative, proactive and risk-seeking } \\
\text { behaviour that crosses national borders and is intended to create } \\
\text { value in business organizations. }\end{array}$ \\
\hline 6 & $\begin{array}{l}\text { Zahra and George, } \\
(2002, \text { p. } 11)\end{array}$ & $\begin{array}{l}\text {...the process of creatively discovering and exploiting } \\
\text { opportunities that lie outside the firm's domestic markets in the } \\
\text { pursuit of competitive advantage... }\end{array}$ \\
\hline 7 & $\begin{array}{l}\text { Dimitratos and } \\
\text { Plakoyiannaki } \\
(2003, \text { p. } 189)\end{array}$ & $\begin{array}{l}\text {...an organization-wide process which is embedded in the } \\
\text { organizational culture of the firm and which seeks through the } \\
\text { exploitation of opportunities in the international marketplace to } \\
\text { generate value. }\end{array}$ \\
\hline 8 & $\begin{array}{l}\text { Oviatt and } \\
\text { McDougall, (2005a, } \\
\text { p.540) }\end{array}$ & $\begin{array}{l}\text {..the discovery, enactment, evaluation, and exploitation of } \\
\text { opportunities - across national borders - to create future goods and } \\
\text { services. }\end{array}$ \\
\hline 9 & $\begin{array}{l}\text { Styles and Seymour, } \\
(2006, \text { p.134) }\end{array}$ & $\begin{array}{l}\text {...is the behavioural processes associated with the creation and } \\
\text { exchange of value through the identification and exploitation of } \\
\text { opportunities that cross national borders... }\end{array}$ \\
\hline 10 & $\begin{array}{l}\text { Mathews and Zander } \\
(2007, \text { p.389) }\end{array}$ & $\begin{array}{l}\text {...entrepreneurial processes that stretch across the discovery of } \\
\text { new business opportunities in an international context to aspects of } \\
\text { exploitation including the redeployment of resources and the } \\
\text { ultimate engagement with competitors that takes place before } \\
\text { organisational and industry maturity sets in. }\end{array}$ \\
\hline 11 & $\begin{array}{l}\text { Karra et al. }(2008, \\
\text { pp. } 441-442)\end{array}$ & $\begin{array}{l}\text {...the best definition of international entrepreneurship is } \\
\text { one based on international resources configurations" and } \\
\text { "international entrepreneurship involves building competitive } \\
\text { advantage by developing complex international resource } \\
\text { configuration". }\end{array}$ \\
\hline 12 & $\begin{array}{l}\text { Zahra et al. } \\
(2014, \text { p. } 138)\end{array}$ & $\begin{array}{l}\text {...is the recognition, formation, evaluation, and exploitation of } \\
\text { opportunities across national borders to create new businesses, } \\
\text { models, and solutions for value creation, including financial, } \\
\text { social, and environmental... }\end{array}$ \\
\hline
\end{tabular}

Note: Other studies similar to this have also compiled IE definitions, and have included the International New Ventures definition of Oviatt and McDougall (1994). It should be noted that this definition refers explicitly to the INVs and not to the International Entrepreneurship. Therefore, in this research has not been taken into account. 
The most striking feature of the definition offered by McDougall (1989) is that it restricts the field of research to the study of new firms and their rapid internationalisation. Interestingly, all subsequent definitions have progressively incorporated new concepts into their definitions, according to Oviatt and McDougall (2005a). However, all concepts introduced in the definitions are associated with the phenomenon of internationalisation. Hence, internationalisation is the first common concept in all definitions. It should be noted that authors have referred to this concept in different ways, such as "across national borders" (McDougall and Oviatt, 1997; Oviatt and McDougall, 2005a; Zahra et al., 2014), "that cross national border[s]" (Styles and Seymour, 2006), "that crosses national border[s]" (McDougall and Oviatt, 2000; Wright and Ricks, 1994), and "outside the domestic market" (Zahra and George, 2002), among others. Nonetheless, it is important to highlight that they all refer to the internationalisation of a business organisation.

All definitions imply dynamism, which refers to an activity, process or behaviour. In this sense, Wright and Ricks (1994) and McDougall and Oviatt (1997) suggested that IE implies an "activity". Likewise, Zahra and George (2002) and Dimitratos and Plakoyiannaki (2003) related it to a "process". Sytles and Seymour (2006) and Mathews and Zander (2007) affirmed that this process is behavioural and entrepreneurial. Zucchella and Magnani (2016) pointed out that the IE field is increasingly viewed as a process since they have seen an evolution in definitions from a static perspective (the creation act) to a dynamic perspective (the entrepreneurial process). In addition, many of the definitions developed until 2000 (McDougall and Oviatt, 2000) are linked to this process from some dimension of entrepreneurial orientation, i.e., with an innovative, proactive and risk-seeking behaviour. Subsequently, after the definition of Zahra and George (2002), the definitions start to describe this process as a sequence of phases that are related to the recognition and exploitation of international entrepreneurial opportunities. For example, Oviatt and McDougall (2005b) described this process as the discovery, promulgation, evaluation and exploitation of opportunities. Zahra et al. (2014) described this process as the recognition, formation, evaluation and exploitation of opportunities.

The concept of the recognition of opportunities is another key dimension in IE definitions. Opportunity recognition is the beginning of any entrepreneurial process and plays a relevant role in the entrepreneurial internationalisation of firms (Fletcher, 2004; Zahra et al., 2005). Thus, the IE literature has assumed that firms that manage to recognise opportunities in other markets will trigger, catalyse and promote their international expansion with greater ease (Butler et al., 2010). Although not studied in depth, the incorporation of this concept into the IE definition is important because it further connects the IE field with entrepreneurship research (Keupp and Gassmann, 2009).

The last concept that is perceived in the definition of the field IE is the one of value creation. Owing to its importance for the strategic success of firms, this concept is considered a central notion in several fields of research. In fact, the general proposal of all research lines of 
business and management is that value creation over time is the ultimate objective of all firms. However, the recent economic and financial crises, the social and religious tensions in several countries, the inequalities in income distribution and welfare as well as unresolved climate issues have, to some extent, changed the concept of value creation, which is extending beyond the particular interests of shareholders. In this way, the current tendencies consider the value created by companies to be distributed to the different stakeholders: to its primary stakeholders in the form of dividends, to its employees in the form of salaries and to its customers through goods and services, to mention a few examples (Teti et al., 2014). McDougall and Oviatt (1997) introduced value creation as a central concept in the definition of IE. This was necessary since entrepreneurs' primary driver for international activities is value creation through cross-border resource combinations (Autio, 2005). Furthermore, the IE field seems to adapt to the ideology of value distribution among different stakeholders as international entrepreneurs exchange and co-create value with a variety of different actors, including suppliers, customers, society, financiers and even competitors (Styles and Seymour, 2006; Teti et al., 2014). Finally, the last IE definition proposed by Zahra et al. (2014) expands the concept of value creation towards a dimension of global actuality, such as the creation of social and environmental value by companies.

The analysis of the above definitions shows that since the first definition found in the literature (McDougall 1989), the definitions have gradually incorporated conceptual elements that distinguish and characterise the IE field. This shows a clear evolution of the definitions and, consequently, the scope of the field. However, IE has been criticised for its difficulties in distinguishing literature belonging to the IE field (Keupp and Gassmann, 2009). Hence, it is necessary to continue analysing and discussing the barriers that create confusion in this field. This practice will improve understanding and better clarify the domain of IE.

As part of this analysis and discussion, this paper suggests that this confusion is the result of three specific barriers: (1) the variation between the different definitions of the IE field, (2) the conceptual disparity in relation to the categorisation of the rapidly internationalising firms, and (3) the inclusion of research that compares national entrepreneurial behaviour between cultures or countries.

First, efforts to position IE as independent of the size and age of firms originate from the work of Zahra (1993). This researcher argues that "international start-ups represent only one type of IE" and that entrepreneurial behaviour is a process performed not only by new firms but also by the larger, more established companies. In this study, IE is considered an entrepreneur phenomenon that occurs from the moment that companies - new and/or established - decide to enter international markets. The subsequent definitions validated this new phenomenological scope of IE. However, Coviello and Jones (2004) and Keupp and Gassmann (2009) have noted that despite the new domain, the vast majority of IE studies is limited to the analysis of new and small firms. In this sense, the present review also shows that the vast majority of empirical papers tends to focus on the study of new firms (91\% of the studies in our sample). 
Another notable aspect that has been previously suggested is that the large number of definitions makes it difficult to distinguish a typical IE field of study (Keupp and Gassmann 2009). This situation is detrimental because the studies that develop research in this field are unable adopt one of the many definitions to legitimise their investigations. However, the progress in the IE field has been positive, especially following the development of the definition by Oviatt and McDougall in 2005, as noted by a significant increase of citations in the IE research. The increase in IE studies in the last 10 years that are focused on entrepreneurial internationalisation in both new and established firms $(83 \%$ and $91 \%$, respectively) is proof of this positive change. It is possible that these results are a consequence of wider acceptance and consolidation of the theoretical frameworks that explain the IE field.

Second, there is still considerable terminological confusion regarding the labelling of rapidly internationalising firms. In the IE literature, various terms have been incorporated to denote firms that perform rapid internationalisation. Some of these terms include "Born Globals" (BGs) (Rennie, 1993), "International New Ventures" (INVs) (Oviatt and McDougall, 1994), "Global Start-ups" (Oviatt and McDougall, 1995) and "Instant Internationals" (Fillis, 2001). These firms have been defined and categorised according to their distinctive characteristics. Some the dimensions that are commonly used for this area include the percentage of foreign sales, time, the geographical scope and the type of industry to which they belong. From an objective view, these criteria have hampered any attempt at differentiation between them. This confusion is especially evident when comparing the concepts of INVs and BGs. Recently, Cavusgil and Knight (2015) clarified the possible differences between BGs and INVs, noting that the mode of entry into foreign markets is one of the main differences. However, despite these clarifications, these terms continue to be used interchangeably. Thus, this terminological confusion is analysed through the four criteria most often used. The first criterion used by studies is the percentage of foreign sales and is used to define both INVs (Shrader et al., 2000; Zhou et al., 2010) and BGs (Kuivalainen et al., 2007; Luostarinen and Gabrielsson, 2006). However, in defining both types of ventures, studies use a similar, or even the same, sales percentage. Therefore, both Shrader et al. (2000) and Kuivalainen et al. (2007) used the same percentage to classify both INVs and BGs (25\% of sales abroad). A second criterion that is widely used is the speed of internationalisation, which is measured by the period of time between the founding of the firm and the first year of internationalisation. Here, there is also some confusion regarding the number of years used to distinguish between BGs and INVs. According to Zhou et al. (2010), INVs make their first foray abroad within the first three years of their foundation. This statement also coincides with that provided by Kuivalainen et al. (2007) in its definition of BGs. Coviello et al. (2011) note that the most distinctive terms are the use of the concepts "new" and "born" and suggest the need to clarify the stage in a firm's life cycle in which it is internationalised. However, the "Born Global" term was attributed by Rennie (1993) to companies that did not start their international operations from the "born" date but rather two years after their foundation.

A third criterion in the research for differentiating these companies is the scope with regard to penetrated markets, i.e., the number of countries in which they operate. However, in the 
initial definitions that Oviatt and McDougall (1994) and Rennie (1993) provided of INVs and BGs, they did not indicate a specific number of countries and only mention the existence of a rapid international expansion of firms. In this sense, some authors have found in the terms "international" and "born" a possible way to differentiate between the types of firms. Thus, Luostarinen and Gabrielsson (2004) have suggested that "international" term refers to international expansion within the continent of origin, whereas "global" can be defined as an expansion beyond the continent of origin. Likewise, Coviello et al. (2011) pointed out that the "international" term refers to sales that cross the borders of a single or a few countries, whereas "global" is reserved for the involvement in many countries or continents. However, despite the efforts to differentiate these terms, it is necessary to remember that both concepts originally referred to the rapid internationalisation of firms regardless of their international scope.

A fourth criterion that is used to categorise rapidly internationalising firms is the industrial sector in which they operate. In some studies, BG firms are specifically catalogued as firms operating in high-tech industries. However, this seems contradictory because when Rennie (1993) introduced the term "Born Globals", he did not restrict it to high-tech companies or specific sectors of a country's economy; it was an activity that firms of all industries could perform.

The divergences described above raise doubts regarding the need to use different terms. The discussions show that the IE field lacks clarity and practicality in the differentiation of new firms that are certainly moulded by the same phenomenon: rapid internationalisation. Thus, the most appropriated trend would be to terminologically combine the rapid internationalisation concept and emphasise the specific indicators of the investigated companies. In addition, the fusion of the concepts would allow a better understanding of the IE field and speak of only one phenomenon - rapid internationalisation - instead of using different terms, which hinder the understanding and development of this area in the IE field.

Finally, in this work, it is suggested that the extension of the IE domain to include comparative research on entrepreneurship between countries represents a barrier that prevents a better understanding of the field. These attempts date back to the definition proposed by McDougall and Oviatt when they included "research comparing domestic entrepreneurial behaviour in multiple countries" (McDougall and Oviatt, 2000). The same authors subsequently validated this new branch of the field without further explanation (Oviatt and McDougall, 2005a). However, this expansion does not seem to be fully accepted in the literature and causes discrepancy between scholars in the IE field (Jones et al., 2011; McDougall et al., 2014; McDougall and Oviatt, 2000; Oviatt and McDougall, 2005b; Terjesen et al., 2016; Zahra et al., 2014). In this literature review, a significant shortage of such cross-national or cross-cultural studies is found, and none of the papers mentioned that this issue contributes to the IE field. However, this may be a consequence of the ambiguity produced by this type of study within the field.

The main reason why these studies are a barrier is that they misinterpret the 
phenomenological sense of the field. To support this assertion, it is necessary to distinguish the true phenomenon that is being studied by each particular field. In the case of the IE field, from its beginnings, it has focused on explaining the internationalisation phenomenon through the entrepreneurial behaviour view of the actors. In contrast, the field of entrepreneurship has been responsible for studying the phenomena that lead an individual to become an entrepreneur (or not) in a domestic context (Acs et al., 2016). Therefore, although both fields are closely related, it is clear that the research focus of each field is the study of different phenomena in different contexts: one at the national level and the second at the international level. Moreover, even if both entrepreneurship and IE are studied from a comparative perspective at the transnational level, they will continue to observe the particular phenomenon corresponding to each field. This can be supported by several cross-national (or cross-cultural) studies on the entrepreneurship phenomenon. Tiessen (1997), for example, has noted that cross-cultural studies can advance entrepreneurship research by helping to distinguish between the relationships that are universally valid and those that are culturally dependent. Likewise, Hayton et al. (2002) pointed out that behavioural and cultural research at the transnational level is necessary to understand its possible influence on the entrepreneurship in countries. None of these studies indicates that it is helping to improve the understanding of entrepreneurial internationalisation. Some authors have also suggested that the inclusion of these studies within the IE field might be useful to international actors to gain a greater appreciation of how they might enter a wider variety of country-markets (Engelen et al., 2009; Gray and Farminer, 2014). However, it is evident that these investigations overlap with one of the central objectives of entrepreneurship, which is to find how entrepreneurial activities differ between countries (Acs et al., 2016). In addition, if one takes into account that entrepreneurship is a social phenomenon (Thornton et al., 2011), then the discussion can be supported in the social sciences research methodology literature. In this sense, Hantrais $(1999,2014)$ pointed out that comparative cross-country research shares the concern for a common social phenomenon, and its objective is to develop explanations based on similarities or differences as well as to assess their consequences and understand how social processes work. Hence, it is evident that comparative studies of entrepreneurship among countries explain phenomena that are more associated with entrepreneurship than with entrepreneurial internationalisation.

Finally, it is true that international comparative studies are increasingly important within social science research (Morren et al., 2012). In fact, in the IE field, Jones et al. (2011) found some studies that compared entrepreneurial internationalisation among countries and logically included them as an important stream of the IE field, suggesting that they are the "crux" of the IE field. However, it is suggested that the extension of IE to include comparative studies of entrepreneurship among countries is problematic and can cause ambiguity in the understanding of the field. This occurs because these studies attempt to explain a phenomenon that is evidently studied by another field of research and completely move away from the phenomenological part initially defined in IE research, namely, entrepreneurial internationalisation. Hence, since this is an issue of great importance, it is necessary to provide a more in-depth discussion in the IE literature. 


\subsection{Perspectives on future tendencies in the field}

The previous sections have noted that IE has undergone significant changes, especially in the scope of the domain, which currently focuses on entrepreneurial internationalisation in all types of companies, both new and established. Likewise, as shown by the previous reviews, the IE research continues to pay greater attention to new and small firms (Coviello and Jones, 2004; Jones et al., 2011; Keupp and Gassmann, 2009; Rialp et al., 2005). Several claims have been made in this regard to balance the literature. From the review of the 272 articles, this study identifies a series of possible trends that are fundamental to balancing the IE field.

In recent years, entrepreneurial orientation (EO) appears to be a key transversal and recurrent concept included in IE research (Covin and Miller, 2014; Freeman and Cavusgil, 2007). EO represents the strategic choice or orientation towards a dynamic process of seeking new opportunities for creating business. EO is composed of three dimensions: innovation, proactiveness and risk taking (Covin and Slevin, 1989). In fact, EO has been implicitly incorporated into the definition of IE proposed by McDougall and Oviatt (2000): “...a combination of innovative, proactive and risk-seeking behaviour that crosses national borders and is intended to create value in organizations". This has led some researchers from IE to incorporate the concept of International Entrepreneurial Orientation (IEO). Freeman and Cavusgil (2007), for example, have defined IEO as "...the behavioural elements of a global orientation [that capture] top management's propensity for risk taking, innovativeness, and proactiveness". Thus, the IEO concept has been recognised by researchers, and it has been assumed that the process of entrepreneurial internationalisation is the sum of the three dimensions of EO conducted in the international context (Covin and Miller, 2014). Moreover, although the EO concept has been frequently mentioned in the IE literature, the results presented indicate that IE research has not paid much empirical attention to this concept. Indeed, only $6.7 \%$ of the empirical articles in this paper have analysed entrepreneurial internationalisation from the EO perspective. Thus, the future of IE literature regarding this concept is promising, not only for research focused on rapid internationalisation but also for studies focused on the more mature firms. In the same direction, Dimitratos et al. (2012) conceptualised the International Entrepreneurial Culture (IEC), which is focused on six interrelated dimensions: international market orientation, international learning orientation, international innovation propensity, international risktaking attitude, international networking orientation, and strong international motivation. Although studies focusing on the concept of the IEC are scarce, these dimensions capture the international entrepreneurial activities of all firms - both new and established - that seek to identify and exploit opportunities abroad.

Another theoretical concept that can be transversal and is included among the different streams of the IE field is that of international entrepreneurial opportunities (Mainela et al., 2014; Styles and Seymour, 2006). The literature indicates that the process of recognition or identification of an opportunity is the beginning of all entrepreneurial activity and plays an important role in the entrepreneurial internationalisation of firms (Fletcher, 2004; Jones and Coviello, 2005; Zahra et al., 2005). Likewise, Butler et al. (2010) emphasise that 
international opportunities trigger, catalyse, and drive the international expansion of the entrepreneurial firms. The evident importance of "opportunities" in entrepreneurial internationalisation has led some researchers in the IE field to request that greater attention be paid to international opportunities (Dimitratos and Jones, 2005). However, this review confirms that empirical studies in the IE field have still paid little attention to the process of recognition and exploitation of international opportunities. The results indicate that only eight empirical articles from the sample are focused on explaining the international opportunities process, of which five are case studies written in the last five years (see Table A1 in the Appendix A).

A theoretical framework that can bring value to IE literature and integrate the differences in the field is decision-making theory. According to Wennekers and Thurik (1999) and Verheul et al. (2002), entrepreneur decision-making considers characteristics such as personal preferences, environmental factors, and individual characteristics. Furthermore, entrepreneurs make decisions with a degree of uncertainty because they consider multiple variables related to risk and reward (Blanco-Mesa et al., 2017). Additionally, the changing market conditions and a possible increase of the opportunity costs can cause more uncertainty in individuals, hindering the process of entrepreneurial decision-making (BlancoMesa et al., 2017). Thus, international entrepreneurs perceive these aspects, and intuition and personal knowledge play a prominent role in making a decision to complement the information limitations of the changing international environment. However, the decisionmaking process in these scenarios is not well understood since it is difficult to determine how the degree of subjectivity and entrepreneurial attitude can influence it. In this sense, the traditional decision-making tools may not be appropriate to explain entrepreneurial internationalisation. Recently, Blanco-Mesa et al. (2017) proposed a new methodology that allows entrepreneurs to aggregate subjective and objective information simultaneously in the decision-making process under uncertainty. This new approximation shows the importance of the entrepreneur. Hence, the development of this theory, including the factors influencing internationalisation decision-making, could be crucial to understanding the process that entrepreneurs conduct to initiate the internationalisation of entrepreneurship. Finally, decision-making theory focusing on the entrepreneur would have a broader scope since it would allow the balancing of the IE literature in terms of the unit of analysis normally selected to explain the phenomena associated with this field.

Another theoretical framework related to decision-making theory that may be important in the future development of IE literature is Effectuation Theory. This theory is a type of alternative logic to causality and explains how entrepreneurs, in conditions of high uncertainty, create opportunities, basing their decisions on the principle of economic loss and not on maximising expected returns. Sarasvathy (2001) argues that causation processes are more effective in static environments where it is possible to predict the future, whereas effectuation processes are regarded as more effective when the future is unpredictable. The literature also points out that effectuation is especially useful when human behaviour, under conditions of high uncertainty, becomes the most important factor in determining the future (Sarasvathy, 2001). This theory is consistent with the study of entrepreneurial 
internationalisation since entrepreneurs make their internationalisation decisions under a high level of risk and uncertainty (Sarasvathy et al., 2014).

Although results indicate that Effectuation Theory is still scarce in the IE literature, it could contribute significantly to the progress of the field in several aspects. First, it would confer the advantage of considering the individual or company and the environment/network from a more consistent process perspective (Andersson, 2011). In this sense, Effectuation Theory could contribute to the literature by explaining the decision-making process of the entrepreneur throughout the process of internationalisation of his business. Second, it is well known that the entrepreneur plays a fundamental role in the entrepreneurial internationalisation process (Jones and Coviello, 2005). However, the IE research tends to focus more on firms than on entrepreneurs (see Table 5). Effectuation Theory could be, in this sense, an interesting alternative to advance the study of entrepreneurial internationalisation from the perspective of the entrepreneur and, thus, to balance the IE research.

In a similar way, the Dynamic Capabilities Perspective could positively contribute to the development of the IE literature. The seminal works of Teece and Pisano (1994) and Teece et al. (1997) refer to the concept of dynamic capabilities as a set of skills of an organisation and its manager to address complex and rapidly changing environments within the limitations of certain path dependencies. Since then, the dynamic capabilities concept has achieved acceptance among researchers regarding its role in business processes, including internationalisation (Eriksson et al., 2014). Dynamic capabilities are about the organisational characteristics necessary to evaluate and seize the opportunities identified as the most promising, such as opportunities to enter into other foreign markets, whether for sales or for conducting research or manufacturing (Pehrsson et al., 2015). In the IE context, the dynamic capabilities framework seems to be promising. Weerawardena et al. (2007) suggest that incorporating the dynamic capabilities view would allow the ability to capture the development of capabilities that facilitates the accelerated internationalisation of BG firms. Prange and Verdier (2011) go beyond this suggestion and argue that dynamic capabilities may be tailored to firms' specific internationalisation processes, either incrementally or accelerated. Finally, Al-Aali and Teece (2014) point out that the dynamic capabilities view, with its emphasis on opportunity identification and timely response in complex environments, naturally fits well in all the currents of the entrepreneurial internationalisation literature. Although the dynamic capabilities literature has grown over recent years, the results of this work indicate that only three empirical articles have used this theoretical framework to explain entrepreneurial internationalisation. Therefore, it is suggested that the use of this theoretical perspective should continue to increase in the IE field.

Another interesting line to develop in this field is the entrepreneurial internationalisation of the family business. This type of business constitutes the majority of all companies in the world. Therefore, these businesses are key to any economy. Their property characteristics allow them to adapt to changing environments, launch products and enter international markets that other investor-led firms cannot address (Dyer and Whetten, 2006). The evidence 
on this issue is diverse. Bell et al. (2004) consider family ownership to be linked to a "cautious and more reluctant approach to internationalisation", and firms that have become international have done so following more traditional internationalisation. Other studies, such as Kontinen and Ojala (2012), note that the transfer of ownership can be a factor that influences the internationalisation of these companies. In fact, Graves and Thomas (2008) provided evidence of family firms becoming rapidly internationalised to several countries in the context of a generational change. In spite of this evidence, the influence of characteristics typical of family companies in entrepreneurial internationalisation is a subject that has not yet been fully investigated. Therefore, this is a clear niche of research that should be studied in more detail by IE studies.

Finally, a way of uniting the IE paradigms is through the development of inclusive models of all the phenomenological currents of the field. Keupp and Gassmann (2009) point out that empirical studies of IE are reluctant to use models other than those developed for the study of new firms. An example of these models is the one developed by Jones and Coviello (2005), which integrates certain common elements of both the international business and entrepreneurship field. According to Jones and Coviello (2005), their proposed model is important as it might be experienced by any firm, in any industry, under any circumstances and thus is context free. It is clear that the development of these models - comprehensive and inclusive - can benefit the understanding and integration of the IE field.

\section{Conclusions}

This study conducted an exhaustive literature review on IE, analysing 272 articles published in the top 20 journals of the four areas of business and management according to the Journal Citation Report of the Web of Science. After reviewing the literature, we determined that despite the criticism made by previous reviews, the IE field has continued to exhibit growing scientific productivity from different countries. The objective of this review has been to examine the trend of recent publications regarding some criticisms made by previous reviews.

IE is a field that, from the beginning, has tried to develop a definition that fully represents its phenomenon of study. Over time, although many definitions have been developed, the IE field seems to have found and integrated conceptual elements that distinguish and characterise the field of study, such as internationalisation, the entrepreneurial process, opportunity recognition and value creation. The gradual incorporation of these conceptual elements, their consideration by researchers, and the evident extension of the field domain show a clear evolution of the definition and consequently of the development of the IE field. However, despite apparent progress, the IE field continues to present some controversies that prevent a better understanding of the field. In this sense, we have contributed to several discussions related to the large number of IE definitions that present terminological confusion among rapidly internationalising firms and the tendency to include comparative 
studies of entrepreneurship at the domestic level between countries. Based on these discussions, we suggest that future research and IE scholars discuss these topics in greater depth.

It is also observed that IE studies have begun using some theoretical frameworks from theories of entrepreneurship, such as Effectuation Theory or the Opportunity-based View. The use of these theories could enrich knowledge regarding the entrepreneurial internationalisation process. Moreover, they will encourage a balance between all phenomenological currents of the IE field, i.e., those who study entrepreneurial internationalisation both in new and established companies in a given country or between countries.

The latest research has begun to consider the criticism related to methodological aspects of the field. For example, the growing incorporation of longitudinal studies has been observed. This corrects the tendency of IE researchers to develop static studies (Coviello and Jones, 2004; Keupp and Gassmann, 2009). However, much remains to be done regarding this methodological approach because almost all longitudinal research continues to analyse entrepreneurial internationalisation from a positivist perspective, almost completely ignoring the true complexity of the process of internationalisation. Therefore, studies that explain this whole process, including the departure from the international market and/or the death of firms, will be well received in the field.

Despite progress, this analysis has allowed us to also identify some gaps that can be addressed by future research. The results of this work show that of the empirical documents analysed, only $13.9 \%$ are focused on the individual and $2.4 \%$ on entrepreneurial teams. Therefore, there is a relevant shortage of research that explains entrepreneurial internationalisation from the perspective of these enterprising actors. In this sense, the IE literature has indicated from the outset that entrepreneurial internationalisation is the result of the behaviour and entrepreneurial skills of the individual or the entrepreneurial team (Autio, 2005; Oviatt and McDougall, 2005a). The entrepreneurial teams are responsible for collecting information, identifying and exploiting international opportunities and selecting appropriate business strategies. Furthermore, they are responsible not only for the export behaviour of their companies but also for their subsequent export and the overall performance of the firm (Fernhaber and Li, 2013). Hence, future research should focus more on entrepreneurs or entrepreneurial teams as the units of analysis and examine their entrepreneurial behaviour at the beginning of the internationalisation of their companies. Thus, this study proposes a series of theoretical frameworks and models that may be useful in dealing with this gap, including the Opportunity-based View, Decision-making Theory, Effectuation Theory, Entrepreneurial Orientation, Dynamic Capabilities or the International Entrepreneurial Behaviour Model proposed by Jones and Coviello (2005). These frameworks may be relevant for the future of IE, not only to balance the literature regarding the unit of analysis but also because they would allow the analysis of the entrepreneurial behaviour of different entrepreneurial actors before internationalisation. 
In relation to the geographical context in which this phenomenon has been studied, it was found that there is limited literature in economically emerging contexts. Studies contextualised in countries such as Latin America are very interesting because they are making significant efforts to promote the internationalisation of new and small firms (Acs and Amorós, 2008; Dimitratos et al., 2014). Some authors (Browen and De Clercq, 2008; Cheng and $\mathrm{Yu}, 2008$; Oparaocha, 2015) indicate that the role of the country context is a critical issue for the progress of research in IE. Countries and their specific economic, institutional, political and social systems generate unique environments and are attractive to the study of different entrepreneurial phenomena, including IE. Hence, it is important that future research should give greater emphasis to IE studies in emerging economies to assess whether the perspectives developed in mature markets are also valid in emerging economies. In this sense, this analysis also confirms that comparative studies between different economies are still limited; therefore, such studies should be developed in the future.

Some of the practical implications of this work are mainly oriented towards policy makers. The dynamics of different environments and the development of technologies have allowed the internationalisation not only of established companies but also of new firms. This paper analyses the literature that studies these phenomena and therefore indirectly provides evidence of a growing, increasingly intense and global phenomenon.

The IE literature indicates that entrepreneurial internationalisation is beneficial to the development of economies. Therefore, policymakers, particularly those from emerging economies, should draw upon this work to motivate the comprehensive study of entrepreneurial internationalisation in each of their contexts. In turn, they should create or enhance their entrepreneurial ecosystems or business networks and disseminate among them policies that allow and facilitate the internationalisation of new and small companies.

This study is not without limitations. The selection of the 20 higher impact journals according to the four main areas of business and management (international business, entrepreneurship, management and technological and innovation management) has led us to exclude other journals recognised in this young field, such as the Journal of International Entrepreneurship. However, we believe that this literature review provides a fairly complete picture of the current state of the IE literature and how these studies have progressed and responded (or not) to criticism by other authors.

Finally, as Coviello et al. (2011) point out, the IE field has managed to differentiate itself and gain some legitimacy. However, the current characteristics of the literature and the ambiguity of the domain lead us to classify it as a field that is still growing and is not in a state of maturity, as some authors have suggested (Von Krogh et al., 2012). This study not only attempts to provide a clear and complete picture of IE research so far but also offers a critical reflection on the most relevant barriers that hinder the proper understanding and definition of the domain, helping to establish a roadmap for future IE researchers. Therefore, we call for researchers to continue nurturing the theoretical foundations to give IE the legitimacy it deserves. 


\section{References}

Acs, Z. and Amorós, J.E. (2008) 'Entrepreneurship and competitiveness dynamics in Latin America', Small Business Economics, Vol. 31, No. 3, pp.305-322.

Acs, Z.J., Audretsch, D., Lehmann, E.E. and Licht, G. (2016) 'National systems of entrepreneurship', Small Business Economics, Vol. 46, No. 4, pp.527-535.

Al-Aali, A. and Teece, D.J. (2014) 'International entrepreneurship and the theory of the (long- lived) international firm: a capabilities perspective', Entrepreneurship Theory and Practice, Vol. 38, No. 1, pp.95-116.

Andersson, S. (2011) 'International entrepreneurship, born globals and the theory of effectuation', Journal of Small Business and Enterprise Development, Vol. 18, No. 3, pp.627-643.

Autio, E. (2005) 'Creative tension: the significance of Ben Oviatt's and Patricia McDougall's article "toward a theory of international new ventures"', Journal of International Business Studies, Vol. 36, No. 1, pp.9-19.

Bell, J., Crick, D. and Young, S. (2004) 'Small firm internationalization and business strategy: an exploratory study of 'knowledge-intensive' and 'traditional' manufacturing firms in the UK', International Small Business Journal, Vol. 22, No. 1.

Blanco-Mesa, F., Gil-Lafuente, A.M. and Merigó, J.M. (2017) 'New aggregation operators for decision-making under uncertainty: an applications in selection of entrepreneurial opportunities', Technological and Economic Development of Economy, pp.1-23.

Both, A., Papaioannou, D. and Sutton, A. (2014) Systematic Approaches to a Successful Literature Review, 1st ed., Sage Publications, Inc., London, UK.

Browen, H. and De Clercq, D. (2008) 'Institutional context and the allocation of entrepreneurial effort', Journal of International Business Studies, Vol. 39, No. 4, pp.747-767.

Brush, C.G., Manolova, T.S. and Edelman, L.F. (2008) 'Separated by a common language? Entrepreneurship research across the Atlantic', Entrepreneurship: Theory and Practice, Vol. 32, No. 2.

Butler, J.E., Doktor, R. and Lins, F.A. (2010) 'Linking international entrepreneurship to uncertainty, opportunity discovery, and cognition', Journal of International Entrepreneurship, Vol. 8, No. 2, pp.121-134.

Cavusgil, S.T. and Knight, G.A. (2015) 'The born global firm: an entrepreneurial and capabilities perspective on early and rapid internationalization', Journal of International Business Studies, Vol. 46, No. 1, pp.3-16.

Cheng, H.-L. and Yu, C.-M.J. (2008) 'Institutional pressures and initiation of internationalization: evidence from Taiwanese small- and medium-sized enterprises', International Business Review, Vol. 
17, No. 3, pp.331-348.

Coviello, N. and Jones, M. (2004) 'Methodological issues in international entrepreneurship research', Journal of Business Venturing, Vol. 19, No. 4, pp.485-508.

Coviello, N., McDougall, P.P. and Oviatt, B.M. (2011) 'The emergence, advance and future of international entrepreneurship research - an introduction to the special forum', Journal of Business Venturing, Vol. 26, No. 6, pp.625-631.

Covin, J.G. and Miller, D. (2014) 'International entrepreneurial orientation: conceptual considerations, research themes, measurement issues, and future research directions', Entrepreneurship Theory and Practice, Vol. 38, No. 1, pp.11-44.

Covin, J.G. and Slevin, D.P. (1989) 'Strategic management of small firms in hostile and benign environments', Strategic Management Journal, Vol. 10, No. 1, pp.75-87.

Dean, M.A., Shook, C.L. and Payne, G.T. (2007) 'The past, present, and future of entrepreneurship research: Data analytic trends and training', Entrepreneurship Theory and Practice, Vol. 31, No. 4, pp.601-618.

Dimitratos, P. and Jones, M. (2005) 'Future directions for international entrepreneurship research', International Business Review, Vol. 14, No. 2, pp.119-128.

Dimitratos, P. and Plakoyiannaki, E. (2003) 'Theoretical foundations of an international entrepreneurial culture', Journal of International Entrepreneurship, Vol. 1, No. 2, pp.187-215.

Dimitratos, P., Amorós, J.E., Etchebarne, M.S. and Felzensztein, C. (2014) 'Micro-multinational or not? International entrepreneurship, networking and learning effects', Journal of Business Research, Vol. 67, No. 5, pp.908-915.

Dimitratos, P., Voudouris, I., Plakoyiannaki, E. and Nakos, G. (2012) 'International entrepreneurial culture - toward a comprehensive opportunity-based operationalization of international entrepreneurship', International Business Review, Vol. 21, No. 4, pp.708-721.

Dyer, W.G. and Whetten, D.A. (2006) 'Family firms and social responsibility: preliminary evidence from the S\&P 500', Entrepreneurship Theory and Practice, Vol. 30, No. 6, pp.785-802.

Engelen, A., Heinemann, F. and Brettel, M. (2009) 'Cross-cultural entrepreneurship research: current status and framework for future studies', Journal of International Entrepreneurship, Vol. 7, No. 3, pp.163-189.

Eriksson, T., Nummela, N. and Saarenketo, S. (2014) 'Dynamic capability in a small global factory', International Business Review, Vol. 23, No. 1, pp.169-180.

Fernhaber, S.A. and Li, D. (2013) 'International exposure through network relationships: implications for new venture internationalization', Journal of Business Venturing, Vol. 28, No. 2, pp.316-334.

Fillis, I. (2001) 'Small firm internationalisation: an investigative survey and future research 
directions', Management Decision, Vol. 39, No. 9, pp.767-783.

Fletcher, D. (2004) 'International entrepreneurship and the small business', Entrepreneurship and Regional Development, Vol. 16, No. 4.

Freeman, S. and Cavusgil, S.T. (2007) 'Toward a typology of commitment states among managers of born-global firms: a study of accelerated internationalization', Journal of International Marketing, Vol. 15, No. 4, pp.1-40.

Graves, C. and Thomas, J. (2008) 'Determinants of the internationalization pathways of family firms: an examination of family influence', Family Business Review, Vol. 21, No. 2, pp.151-167.

Gray, B. and Farminer, A. (2014) 'And no birds sing - reviving the romance with international entrepreneurship', Journal of International Entrepreneurship, Vol. 12, No. 2, pp.115-128.

Hantrais, L. (1999) 'Contextualization in cross-national comparative research', International Journal of Social Research Methodology, Vol. 2, No. 2, pp.93-108.

Hantrais, L. (2014) 'Methodological pluralism in international comparative research', International Journal of Social Research Methodology, Vol. 17, No. 2, pp.133-145.

Hayton, J.C., George, G. and Zahra, S.A. (2002) 'National culture and entrepreneurship: a review of behavioural research', Entrepreneurship Theory and Practice, Vol. 26, No. 4, pp.33-52.

Heidenreich, S., Mohr, A. and Puck, J. (2015) 'Political strategies, entrepreneurial overconfidence and foreign direct investment in developing countries', Journal of World Business, Vol. 50, No. 4, pp.793-803.

Johanson, J. and Vahlne, J.-E. (1977) 'Internationalization Process of firm - model of knowledge development and increasing foreign market commitments', Journal of International Business Studies, Vol. 8, No. 1, pp.23-32.

Johanson, J. and Vahlne, J.-E. (1990) 'The mechanism of internationalization', International Marketing Review, Vol. 7, No. 4, pp.11-24.

Jones, M. and Coviello, N. (2005) 'Internationalization: conceptualising an entrepreneurial process of behaviour in time', Journal of International Business Studies, Vol. 36, No. 3, pp.284-303.

Jones, M., Coviello, N. and Tang, Y. (2011) 'International entrepreneurship research (1989-2009): a domain ontology and thematic analysis', Journal of Business Venturing, Vol. 26, No. 6, pp.632-659.

Jorgensen, E.J.B. (2014) 'Internationalisation patterns of border firms: speed and embeddedness perspectives', International Marketing Review, Vol. 31, No. 4.

Kalinic, I. and Forza, C. (2012) 'Rapid internationalization of traditional SMEs: between gradualist models and born globals', International Business Review, Vol. 21, No. 4, pp.694-707.

Karra, N., Phillips, N. and Tracey, P. (2008) 'Building the born global firm - developing entrepreneurial capabilities for international new venture success', Long Range Planning, Vol. 41, 
No. 4, pp.440-458.

Keupp, M.M. and Gassmann, O. (2009) 'The past and the future of international entrepreneurship: a review and suggestions for developing the field', Journal of Management, Vol. 35, No. 3, pp.600633.

Kiss, A., Danis, W. and Cavusgil, S.T. (2012) 'International entrepreneurship research in emerging economies: a critical review and research agenda', Journal of Business Venturing, Vol. 27, No. 2, pp.266-290.

Kontinen, T. and Ojala, A. (2012) 'Internationalization pathways among family-owned SMEs', International Marketing Review, Vol. 29, No. 5, pp.496-518.

Kuivalainen, O., Sundqvist, S. and Servais, P. (2007) 'Firms' degree of born-globalness, international entrepreneurial orientation and export performance', Journal of World Business, Vol. 42, No. 3, pp.253-267.

Luostarinen, R. and Gabrielsson, M. (2004) 'Finnish perspectives of international entrepreneurship', Handbook of Research on International Entrepreneurship, pp.383-403.

Luostarinen, R. and Gabrielsson, M. (2006) 'Globalization and marketing strategies of Born Globals in SMOPECs’, Thunderbird International Business Review, Vol. 48, No. 6, pp.773-801.

Mainela, T., Puhakka, V. and Servais, P. (2014) 'The concept of international opportunity in international entrepreneurship: a review and a research agenda', International Journal of Management Reviews, Vol. 16, No. 1, pp.105-129.

Mathews, J.A. and Zander, I. (2007) 'The international entrepreneurial dynamics of accelerated internationalisation', Journal of International Business Studies, Vol. 38, No. 3, pp.387-403.

McDougall, P.P. (1989) 'International versus domestic entrepreneurship: new venture strategic behavior and industry structure', Journal of Business Venturing, Vol. 4, No. 6, pp.387-400.

McDougall, P.P. and Oviatt, B.M. (1997) 'International entrepreneurship literature in the 1990s and directions for future research', in Sexton, D.L. and Smilor, R.W. (Eds): Entrepreneurship 2000, Upstar Publishing, Chicago, pp.291-320.

McDougall, P.P. and Oviatt, B.M. (2000) 'International entrepreneurship: the intersection of two research paths', Academy of Management Journal, Vol. 43, No. 5, pp.902-906.

McDougall, P.P., Jones, M.V. and Serapio, M.G. (2014) 'High-potential concepts, phenomena, and theories for the advancement of international entrepreneurship research', Entrepreneurship Theory and Practice, Vol. 38, No. 1, pp.1-10.

Merigó, J.M., Mas-Tur, A., Roig-Tierno, N. and Ribeiro-Soriano, D. (2015) 'A bibliometric overview of the Journal of Business Research between 1973 and 2014', Journal of Business Research, Vol. 68, No. 12, pp.2645-2653.

Morren, M., Gelissen, J. and Vermunt, J. (2012) 'The impact of controlling for extreme responding 
on measurement equivalence in cross-cultural research', European Journal of Research Methods for the Behavioral and Social Sciences, Vol. 8, No. 4, pp.159-170.

Olejnik, E. and Swoboda, B. (2012) 'SMEs' internationalisation patterns: descriptives, dynamics and determinants', International Marketing Review, Vol. 29, No. 5, pp.466-495.

Oparaocha, G.O. (2015) 'SMEs and international entrepreneurship: an institutional network perspective', International Business Review, Vol. 24, No. 5, pp.861-873.

Oviatt, B.M. and McDougall, P.P. (1994) ‘Toward a theory of International New Ventures’,

Journal of International Business Studies, Vol. 25, No. 1, pp.45-64. Oviatt, B.M. and McDougall, P.P. (1995) 'Global start-ups: entrepreneurs on a worldwide stage', Academy of Management Executive, Vol. 9, No. 2, pp.30-43.

Oviatt, B.M. and McDougall, P.P. (2005a) 'Defining international entrepreneurship and modeling the speed of internationalization', Entrepreneurship Theory and Practice, Vol. 29, No. 5, pp.537554.

Oviatt, B.M. and McDougall, P.P. (2005b) 'The internationalization of entrepreneurship', Journal of International Business Studies, Vol. 36, No. 1, pp.2-8.

Pehrsson, T., Ghannad, N., Pehrsson, A., Abt, T., Chen, S., Erath, F. and Hammarstig, T. (2015) 'Dynamic capabilities and performance in foreign markets: developments within international new ventures', Journal of International Entrepreneurship, Vol. 13, No. 1, pp.28-48.

Prange, C. and Verdier, S. (2011) 'Dynamic capabilities, internationalization processes and performance', Journal of World Business, Vol. 46, No. 1, pp.126-133.

Rennie, M.W. (1993) 'Global competitiveness: born global', The McKinsey Quarterly, Vol. 4, No. 4, pp.45-52.

Rialp, A., Rialp, J. and Knight, G.A. (2005) 'The phenomenon of early internationalizing firms: what do we know after a decade (1993-2003) of scientific inquiry?' International Business Review, Vol. 14, No. 2, pp.147-166.

Sarasvathy, S., Kumar, K., York, J.G. and Bhagavatula, S. (2014) 'An effectual approach to international entrepreneurship: overlaps, challenges, and provocative possibilities', Entrepreneurship Theory and Practice, Vol. 38, No. 1, pp.71-93.

Sarasvathy, S.D. (2001) 'Causation and effectuation: toward a theoretical shift from economic inevitability to entrepreneurial contingency', The Academy of Management Review, Vol. 26, No. 2.

Shrader, R.C., Oviatt, B.M. and McDougall, P.P. (2000) 'How new ventures exploit trade-offs among international risk factors: lessons for the accelerated internationalization of the 21st century', Academy of Management Journal, Vol. 43, No. 6, pp.1227-1247.

Styles, C. and Seymour, R.G. (2006) 'Opportunities for marketing researchers in international entrepreneurship’, International Marketing Review, Vol. 23, No. 2, pp.126-145. 
Sui, S., Yu, Z. and Baum, M. (2012) 'Prevalence and longitudinal trends of early internationalisation patterns among Canadian SMEs’, International Marketing Review, Vol. 29, No. 5, pp.519-535.

Szyliowicz, D. and Galvin, T. (2010) 'Applying broader strokes: extending institutional perspectives and agendas for international entrepreneurship research', International Business Review, Vol. 19, No. 4, pp.317-332.

Teece, D. and Pisano, G. (1994) 'Dynamic capabilities of a firm: an introduction', Industrial and Corporate Change, Vol. 3, No. 3, pp.537-556.

Teece, D., Pisano, G. and Shuen, A. (1997) 'Dynamic capabilities and strategic management', Strategic Management Journal, Vol. 18, No. 7, pp.509-533.

Terjesen, S., Hessels, J. and Li, D. (2016) 'Comparative international entrepreneurship: a review and research agenda’, Journal of Management, Vol. 42, No. 1, pp.299-344.

Teti, E., Perrini, F. and Tirapelle, L. (2014) 'Competitive strategies and value creation: a twofold perspective analysis', Journal of Management Development, Vol. 33, No. 10, pp.949-976.

Thomas, A.S. and Mueller, S.L. (2000) 'A case for comparative entrepreneurship: assessing the relevance of culture', Journal of International Business Studies, Vol. 31, No. 2, pp.287-301.

Thornton, P.H., Ribeiro-Soriano, D. and Urbano, D. (2011) 'Socio-cultural factors and entrepreneurial activity: an overview', International Small Business Journal, Vol. 29, No. 2, pp.105118.

Tiessen, J.H. (1997) 'Individualism, collectivism and entrepreneurship: a framework for international comparative research', Journal of Business V enturing, V ol. 12, No. 5, pp.367-384.

Veciana, J.M. (2007) 'Entrepreneurship as a scientific research programme', in Cuervo, A., Riberio, D. and Salvador, R. (Eds): Entrepreneurship: Concepts, Theory and Perspective, Springer, Heidelberg, pp.23-71.

Verheul, I., Wennekers, S., Audretsch, D. and Thurik, R. (2002) 'An eclectic theory of entrepreneurship: policies, institutions and culture', Entrepreneurship: Determinants and Policy in a European-US Comparison, Kluwer Academic Publishers, Boston, pp.11-81.

Von Krogh, G., Rossi-Lamastra, C. and Haefliger, S. (2012) 'Phenomenon-based research in management and organisation science: when is it rigorous and does it matter?' Long Range Planning, Vol. 45, No. 4, pp.277-298.

Weerawardena, J., Mort, Gi.S., Liesch, P.W. and Knight, G. (2007) 'Conceptualizing accelerated internationalization in the born global firm: a dynamic capabilities perspective', Journal of World Business, Vol. 42, No. 3, pp.294-306.

Wennekers, S. and Thurik, R. (1999) 'Linking entrepreneurship and economic growth', Small Business Economics, Vol. 13, No. 1, pp.27-56.

Wright, R.W. and Ricks, D.A. (1994) 'Trends in international - business research 25 years later', 
Journal of International Business Studies, Vol. 25, No. 4, pp.687-701.

Yamakawa, Y., Peng, M. and Deeds, D. (2008) 'What drives new ventures to internationalize from emerging to developed economies?' Entrepreneurship Theory and Practice, Baylor University, Malden, MA, Vol. 32, No. 1, pp.59-82.

Zahra, S.A. (1993) 'A conceptual model of entrepreneurship as firm behavior: a critique and extension', Entrepreneurship: Theory and Practice, Vol. 17, No. 4, pp.5-21.

Zahra, S.A. and George, G. (2002) 'International entrepreneurship: the current status of the field and future research agenda', in Hitt, M.A., Ireland, R.D., Sexton, D.L. and Camp, M. (Eds): Strategic Entrepreneurship: Creating an Integrated Mindset. Strategic Management Series, Blackwell Publishers, Oxford, UK, pp.255-288.

Zahra, S.A. and Mudambi, R. (2007) 'The survival of international new ventures', Journal of International Business Studies, Vol. 38, No. 2, pp.333-352.

Zahra, S.A., Korri, J.S. and Yu, J. (2005) 'Cognition and international entrepreneurship: implications for research on international opportunity recognition and exploitation', International Business Review, Vol. 14, No. 2, pp.129-146.

Zahra, S.A., Newey, L.R. and Li, Y. (2014) 'On the frontiers: the implications of social entrepreneurship for international entrepreneurship', Entrepreneurship Theory and Practice, Vol. 38, No. 1, pp.137-158.

Zhou, L., Barnes, B.R. and Lu, Y. (2010) 'Entrepreneurial proclivity, capability upgrading and performance advantage of newness among international new ventures', Journal of International Business Studies, Vol. 41, No. 5, pp.882-905.

Zucchella, A. and Magnani, G. (2016) International Entrepreneurship : Theoretical Foundations and Practices, 2nd ed., Palgrave Macmillan UK, London, UK.

\section{Note}

1 According to these authors, the stages to develop a literature review include (1) setting the criteria for selecting studies, (2) identifying relevant studies, (3) selecting relevant studies, (4) charting (extracting) the data and, (4) collating, summarising and reporting the results. 
Table A1 References grouped by theoretical frameworks

\begin{tabular}{|c|c|}
\hline $\begin{array}{l}\text { Theoretical } \\
\text { frameworks }\end{array}$ & References \\
\hline $\begin{array}{l}\text { Non-Specific/ } \\
\text { Multiple }\end{array}$ & 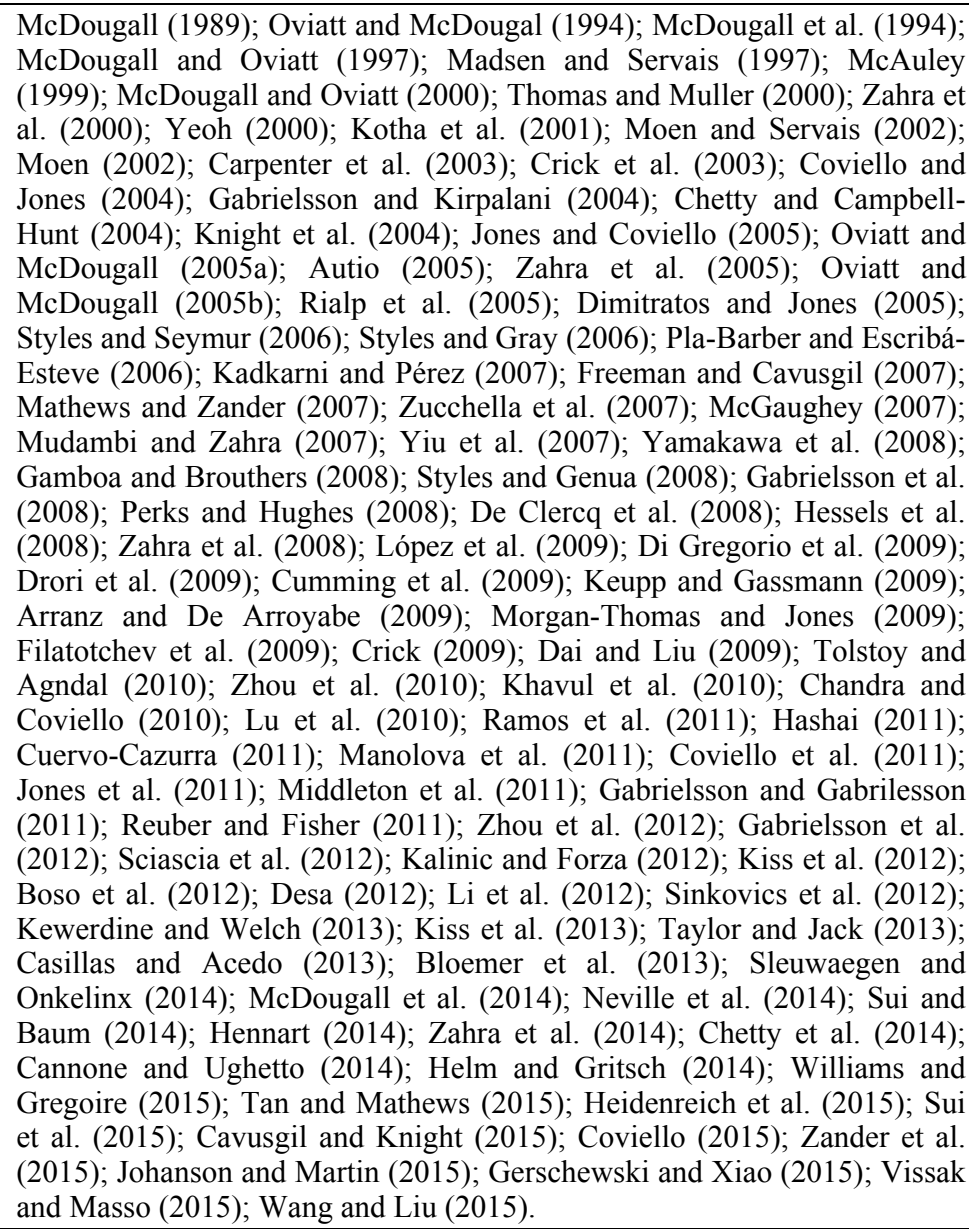 \\
\hline $\begin{array}{l}\text { Resource-Based } \\
\text { View }\end{array}$ & $\begin{array}{l}\text { Jones (1999); Autio et al. (2000); Peng (2001); Westhead et al. (2001); } \\
\text { Kuemmerle (2002); Yli-renko et al. (2002); Kundu and Katz (2003); } \\
\text { Knight and Cavusgil (2004); Crick and Spence (2005); Sapienza et al. } \\
\text { (2006); Spence and Crick (2006); Weerawardena et al. (2007); Loane et al. } \\
\text { (2007); Zhou (2007); Zhang and Dodgson (2007); Gassmann and Keupp } \\
\text { (2007); Presutti et al. (2007); Nordman and Melen (2008); Filatotchev and } \\
\text { Piesse (2009); Casillas et al. (2009); Fernhaber et al. (2009); Reuber and } \\
\text { Fisher (2009); Hughes et al. (2010); Khavul et al. (2010); Freeman et al. } \\
\text { (2010); Prashantham and Young (2011); Autio et al. (2011); Ganotakis and } \\
\text { Love (2012); Evers et al. (2012); Efrat and Shoham (2012); Ripolles and } \\
\text { Blesa (2012); Fletcher and Harris (2012); Robson et al. (2012); da Rocha et } \\
\text { al. (2012); Sigfusson and Chetty (2013); Yamakawa et al. (2013); } \\
\text { Hewerdine et al. (2014); Mohr and Barsakis (2014); Glavas and Mathews } \\
\text { (2014); Loane et al. (2014); Li et al. (2015); Gerschewski et al. (2015); } \\
\text { Park et al. (2015); Casillas et al. (2015) }\end{array}$ \\
\hline
\end{tabular}


Table A1 References grouped by theoretical frameworks (continued)

\begin{tabular}{|c|c|}
\hline $\begin{array}{l}\text { Theoretical } \\
\text { frameworks }\end{array}$ & References \\
\hline $\begin{array}{l}\text { Internationalisation } \\
\text { Theory }\end{array}$ & $\begin{array}{l}\text { Wright and Ricks (1994); Burgel and Murray (2000); Boojihawona et al. } \\
\text { (2007); Liu et al. (2008); Tuppura et al. (2008); Welch and welch (2009); } \\
\text { Schwens and Kabst (2011); Prashantham and Floyd (2012); Kuivalainen } \\
\text { et al. (2012); Olejnik and Swoboda (2012); Kontinen and Ojala (2012); } \\
\text { Freeman et al. (2013); Calabro et al. (2013); Vissak and Francioni } \\
\text { (2013); Al-Aali and Teece (2014); Jorgensen (2014) }\end{array}$ \\
\hline $\begin{array}{l}\text { Neointitutional } \\
\text { Theory }\end{array}$ & $\begin{array}{l}\text { Dimitratos et al. (2004); Di Gregorio (2005); Fan and Phan (2007); } \\
\text { Coerderoy and Murray (2008); Fernhaber et al. (2008); Cheng and Yu } \\
\text { (2008); Nasra and Dacin (2010); Szyliowicz and Galvin (2010); Riddle } \\
\text { and Brinkerhoff (2011); Bangara et al. (2012); Bell et al. (2012); Uner et } \\
\text { al. (2013); Baum et al. (2013); LiPuma et al. (2013); Amoako and Lyon } \\
\text { (2014); Gallego and Casillas (2014) }\end{array}$ \\
\hline $\begin{array}{l}\text { Entrepreneurial } \\
\text { Orientation }\end{array}$ & $\begin{array}{l}\text { Ibeh (2003); Acedo and Jones (2007); Jantunen et al. (2008); Kocak and } \\
\text { Abimbola (2009); Dimitratos et al. (2010); Liu et al. (2011); Selvin and } \\
\text { Terjesen (2011); Ripolles et al. (2012); Sundqvist et al. (2012); Hagen et } \\
\text { al. (2012); Boso et al. (2012); Efrat and Shoham (2013); Covin and } \\
\text { Miller (2014); Brouthers (2015); Fernandez-Mesa and Alegre (2015) }\end{array}$ \\
\hline $\begin{array}{l}\text { Organisational } \\
\text { Learning }\end{array}$ & $\begin{array}{l}\text { Riddle and Gillespie (2003); De Clercq et al. (2005); Bingham (2009); } \\
\text { Schwens and Kabst (2009); Bruneel et al. (2010); Huan and Pervez } \\
\text { (2010); Voudouris et al. (2011); O'Gorman and Evers (2011); Bingham } \\
\text { and Davis (2012); De Clercq and Zhou (2014); Dimitratos et al. (2014); } \\
\text { Musteen et al. (2015); Wu and Voss (2015) }\end{array}$ \\
\hline $\begin{array}{l}\text { Alliance or } \\
\text { Interfirm } \\
\text { Network Theory }\end{array}$ & $\begin{array}{l}\text { Etemad and Lee (2003); Sharma and Blomstermo (2003); Coviello } \\
\text { (2006); Freeman et al. (2006); Loane and Bell (2006); Gleason and } \\
\text { Wiggenhorn (2007); Evers and Knight (2008); De Clercq et al. (2012); } \\
\text { Acs and Terjesen (2013); Milanov and Fernhaber (2014); Nakos et al. } \\
\text { (2014); Hohenthal et al. (2014); Oparaocha (2015) }\end{array}$ \\
\hline $\begin{array}{l}\text { Social } \\
\text { Network } \\
\text { Theory }\end{array}$ & $\begin{array}{l}\text { Harris and Wheeler (2005); Kropp et al. (2006); Sullivan and } \\
\text { Weerawardena (2006); Prashantham and McNaughton (2006); Zhou et } \\
\text { al. (2007); Musteen et al. (2010); Tang (2011); Lindstrand et al. (2011); } \\
\text { Sigfusson and Harris (2013); Pruthi (2014) }\end{array}$ \\
\hline $\begin{array}{l}\text { Opportunities- } \\
\text { Based View }\end{array}$ & $\begin{array}{l}\text { Zahra et al. (2005); Di Gregorio et al. (2008); Chandra et al. (2009); Ellis } \\
\text { (2011); Vasilchenko and Morrish (2011); Kontinen and Ojala (2011); } \\
\text { Chandra et al. (2012); Dimitratos et al (2012); Shin and Lee (2013), } \\
\text { Mainela et al. (2014) }\end{array}$ \\
\hline $\begin{array}{l}\text { Strategic } \\
\text { Entrepreneurship }\end{array}$ & $\begin{array}{l}\text { Zahra (1993); Kuivalainen et al. (2007); Riding et al. (2012); Hallback } \\
\text { and Gabrielsson (2013); Tolstoy (2014); Gonzalez-Pernia et al. (2015); } \\
\text { Khalid and Bhatti (2015); Baum et al. (2015) }\end{array}$ \\
\hline $\begin{array}{l}\text { Dynamic } \\
\text { Capabilities }\end{array}$ & $\begin{array}{l}\text { Fladmoe-Lindquist (1996); Prange and Verdier (2011); Gnizy et al. } \\
\text { (2014); Eriksson et al. (2014); Cumming et al. (2015) }\end{array}$ \\
\hline $\begin{array}{l}\text { Economic } \\
\text { Geography }\end{array}$ & $\begin{array}{l}\text { Andersson (2004); Rothaermel et al. (2006); Mittelstaeds et al. (2006); } \\
\text { Murmann et al. (2015) }\end{array}$ \\
\hline $\begin{array}{l}\text { Experiential } \\
\text { Learning }\end{array}$ & $\begin{array}{l}\text { Michailova and Wilson (2008); Jones and Casulli (2014); Zhou and Wu } \\
\text { (2014) }\end{array}$ \\
\hline $\begin{array}{l}\text { Industrial } \\
\text { Economics }\end{array}$ & $\begin{array}{l}\text { Contractor and Kundu (2004); Fernahber et al. (2007); Colantone and } \\
\text { Sleuwaegen (2010) }\end{array}$ \\
\hline Social Cognition & Luthans and Ibrayeva (2006); Nadkarni et al. (2011) \\
\hline
\end{tabular}


Table A1 References grouped by theoretical frameworks (continued)

\begin{tabular}{ll}
\hline $\begin{array}{l}\text { Theoretical } \\
\text { frameworks }\end{array}$ & References \\
\hline $\begin{array}{l}\text { Effectuation } \\
\text { Theory }\end{array}$ & Sarasvathy et al. (2014); Kalinic et al. (2014) \\
\hline $\begin{array}{l}\text { Transaction } \\
\text { Cost Theory }\end{array}$ & Shrader (2001) \\
\hline Agency Theory & George et al. (2005) \\
\hline $\begin{array}{l}\text { Economic } \\
\text { Theory of } \\
\text { Entrepreneurship }\end{array}$ & Hessels and van Stel (2011) \\
\hline $\begin{array}{l}\text { Attention-based } \\
\text { View (Ocasio) }\end{array}$ & De Clercq et al. (2014) \\
\hline Note: $\quad$ The full list of articles can be obtained from the leading author upon request.
\end{tabular}

Note: The full list of articles can be obtained from the leading author upon request. 